BRUNO CHUEIRI MUSARRA

Automação de subestações - Sistema automático de alívio de carga 
BRUNO CHUEIRI MUSARRA

Automação de subestações - Sistema automático de alívio de carga

Dissertação apresentada à Escola Politécnica da Universidade de São Paulo para obtenção do título de Mestre em Ciências.

São Paulo

2013 
BRUNO CHUEIRI MUSARRA

\section{AUTOMAÇÃO DE SUBESTAÇÕES - SISTEMA AUTOMÁTICO DE ALÍVIO DE CARGA}

Dissertação apresentada à Escola Politécnica da Universidade de São Paulo para obtenção do título de Mestre em Ciências.

Área de Concentração:

Engenharia Elétrica

Orientador:

Prof. Dr. José Antônio Jardini

São Paulo

2013 


\section{DEDICATÓRIA}

Dedico este trabalho à minha esposa Paula que me deu todo o apoio e incentivo para a realização do mestrado. 


\section{AGRADECIMENTOS}

Agradeço aos meus pais, Delzinho e Mariene, e aos meus irmãos, Fellipe e Eduarda, que mesmo longe fisicamente estiveram sempre perto em minha mente e meu coração, gerando forças para minha graduação e pós-graduação.

Agradeço aos amigos da Elipse Software, que viabilizaram minha frequência nas aulas do mestrado e forneceram informações necessárias para realização deste trabalho.

Agradeço ao meu orientador, professor Jardini, por acreditar em meu potencial desde o início, por sua atenção e pelas sábias dicas para que este trabalho fosse produzido com qualidade. 


\section{RESUMO}

Este trabalho consiste em um estudo sobre alívio de cargas aplicado em indústrias que apresentam sistema misto para geração de energia, na qual uma parte da energia elétrica é gerada através de processo próprio (co-geração) e outra parte é suprida pela alimentação fornecida pelo sistema elétrico regional (concessionária). O alívio de cargas consiste em uma técnica de desligamento rápido e seletivo de algumas cargas, visando manter o sistema em equilíbrio durante interrupção emergencial do fornecimento de energia pela concessionária. Este trabalho efetua uma revisão bibliográfica sobre redes de comunicação, norma IEC 61850, sistemas de supervisão e técnicas de alívio de cargas, as quais se tornam ferramentas que viabilizam o alcance do seu objetivo, que é a proposição de um sistema baseado em um software de supervisão de mercado, que executa seu algoritmo adaptativo de alívio de cargas e pré-sensibiliza equipamentos inteligentes de campo (IED's), conectados conforme padrões estabelecidos pela norma IEC 61850, para efetuarem o desligamento de algumas cargas de uma indústria com sistema misto de geração, em caso de distúrbio no fornecimento pela concessionária. O diferencial do sistema proposto neste trabalho consiste na capacidade do algoritmo, executado pelo software de supervisão, em simular a ocorrência de eventos que caracterizam perdas na geração de energia e transferir ordens para os IED's efetuarem os desligamentos de determinadas cargas antes da ocorrência dos desequilíbrios. Dessa forma, a principal contribuição do trabalho é apresentar um sistema preditivo contra possíveis emergências ocorridas na concessionária, ou seja, como o sistema possui ação conjunta entre o algoritmo adaptativo executado pelo software de supervisão e os IED's, conectados segundo padronizações da norma IEC 61850, oferece capacidade para pré-sensibilizar os desligamentos de cargas antes que ocorram os reais eventos de perda de geração de energia elétrica.

Palavras-chave: Alívio. Carga. Automação. Subestações. Indústrias. Geração. Energia. IEC61850. SCADA. Supervisão. 


\begin{abstract}
This work consists on a study about load shedding applied to industries that use mixed systems on energy generation, where part of the electrical energy is generated by own process (co-generation) and the other part is supplied by the regional electrical system (concessionaire). The load shedding consists in a rapid and selective shut-off technique aiming to maintain the system under balance during power interruption events from the concessionaire. This work provides a literature survey over communication networks, the IEC 61850 standard, supervisory control and data acquisition systems (SCADA) and load shedding techniques, which become tools that make possible to reach the work's goal: to propose a system based on a market SCADA software that runs its load shedding adaptive algorithm and pre-sensitize Intelligent Electronic Devices (IED's), connected according to preestablished standards by the IEC 6180 norm for shutting off some loads in a company with a mixed generation system in case of some supplying disturb from the concessionaire. The differential of the proposed system in this work consists in the capacity of the algorithm, run by the SCADA software, of simulating the occurrence of events that characterize losses in energy generation and sending commands to the IED's to shut off specific loads before an unbalance occurs. This way, the main contribution of this work is to present a predictor system against possible emergencies happening in the concessionaire, that is, as the system provides a joint approach between the SCADA system's algorithm and the properly connected IED's, it provides the capacity of pre-sensitizing the load shedding before real events of electrical energy generation loss occur.
\end{abstract}

Key-words: Load shedding. Energy. Co-generation. Energy. IEC61850. SCADA. 


\section{LISTA DE ILUSTRAÇÕES}

FIGURA 1 - MODELO OSI (FONTE: HTTP://RAFAELPINTO1995.BLOGSPOT.COM/2011/02/MODELO-OSI.HTML) . 16

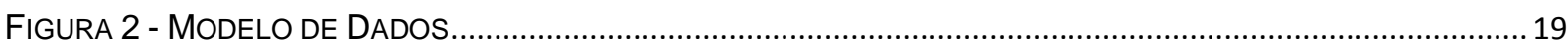

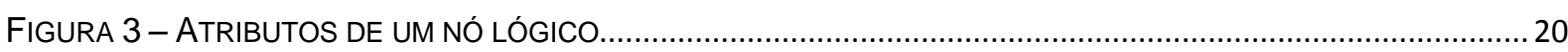

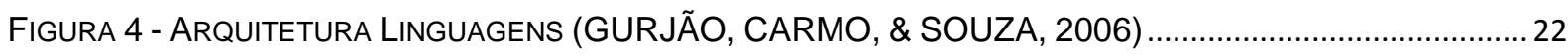

FIGURA 5 - NíveIS HIERÁRQUICOS (PAULINO, SIQUEIRA, \& CARMO, 2010) ………................................. 23

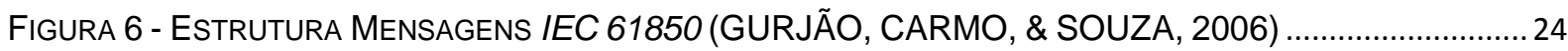

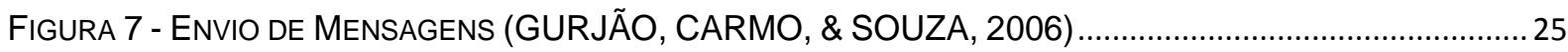

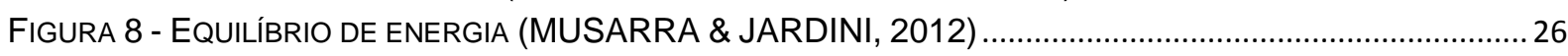

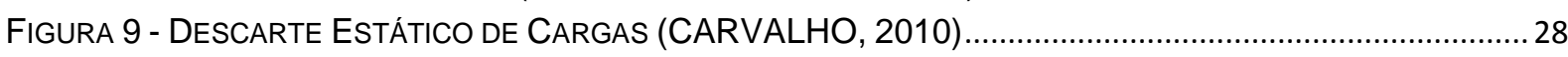

FIGURA 10 - ESTRUTURA ELIPSE POWER (ELIPSE, MANUAL DO ELIPSE POWER, 2013) ....................... 34

FIGURA 11 - ALGORITMO DESCARTE CARGAS (ELIPSE, MANUAL DO ELIPSE POWER, 2013) ................37

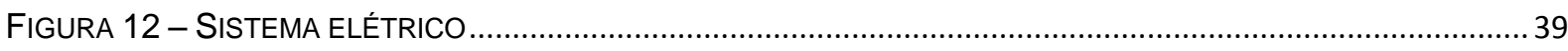

FIGURA 13 - ARQUITETURA SOLUÇÃO (ELIPSE, TUTORIAL ELIPSE POWER, 2012) ................................ 40

FIGURA 14 - ORDENS DE DESLIGAMENTO (ELIPSE, TUTORIAL ELIPSE POWER, 2012) ..........................42

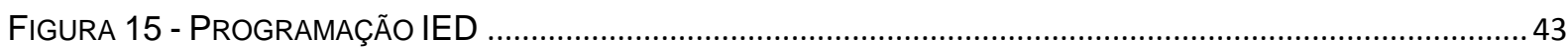

FIGURA 16 - ABERTURA DISJUNTOR (ELIPSE, TUTORIAL ELIPSE POWER, 2012) .................................. 44

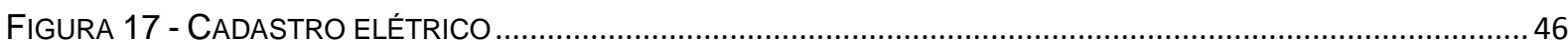

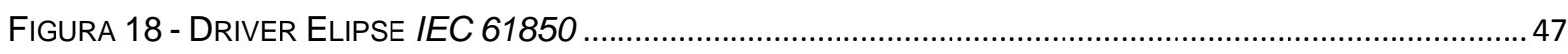

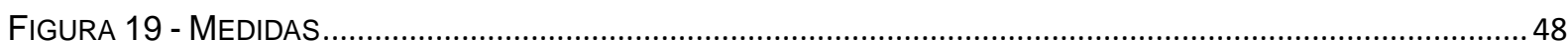

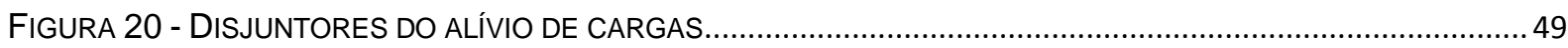

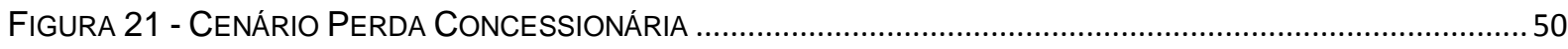

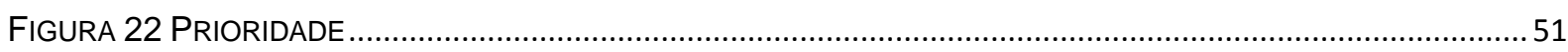

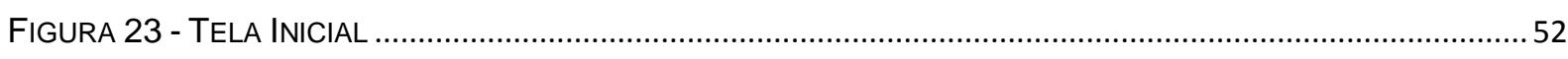

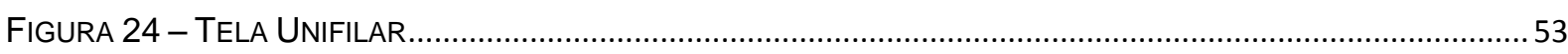

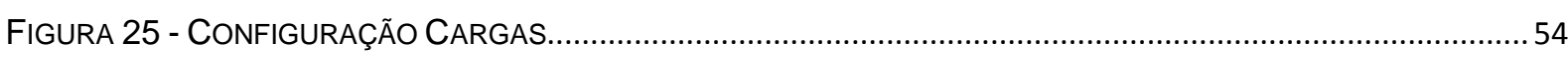

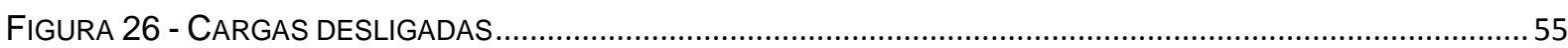

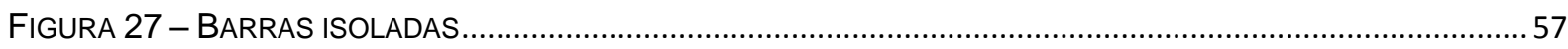

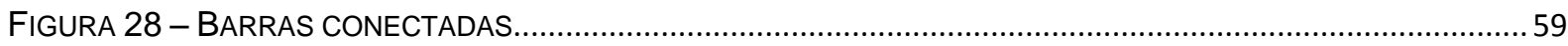

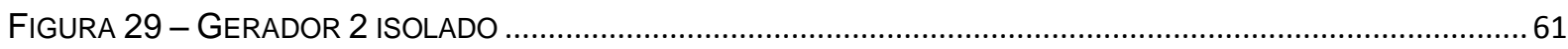




\section{LISTA DE ABREVIATURAS E SIGLAS}

$\begin{array}{ll}\text { CLP's } & \text { Controladores Lógicos Programáveis } \\ \text { CID } & \text { Configured IED Description } \\ \text { DJ } & \text { Disjuntor } \\ \text { DNP 3.0 } & \text { Distributed Network Protocol } \\ \text { GOOSE } & \text { Generic Object Oriented Substation Event } \\ \text { GSE } & \text { Generic Substation Events } \\ \text { GSSE } & \text { Generic Substation State Event } \\ \text { ICD } & \text { IED Capability Description } \\ \text { IEC } & \text { International Electrotechnical Commission } \\ \text { IED } & \text { Intelligent Electronic Device } \\ \text { IHM } & \text { Interface Homem Máquina } \\ \text { IP } & \text { Internet Protocol } \\ \text { ISO } & \text { International Organization for Standardization } \\ \text { LD } & \text { Logical Device } \\ \text { LN } & \text { Logical Node } \\ \text { LT } & \text { Linha de Transmissão } \\ \text { OSI } & \text { Open Systems Interconnection } \\ \text { SCADA } & \text { Supervisory Control and Data Acquisition } \\ \text { SCD } & \text { System Configuration Description } \\ \text { SCL } & \text { Substation Configuration Language } \\ \text { SSD } & \text { Substation Specification Description } \\ \text { TC } & \text { Transformador de Corrente } \\ \text { TC57 } & \text { Technical Committee 57 } \\ \text { TCP } & \text { Transmission Control Protocol } \\ \text { TP } & \text { Transformador de Potencial } \\ \text { UDP } & \text { User Datagram Protocol } \\ \text { UTR's, } & \text { Unidades Terminais Remotas } \\ \text { XCBR } & \text { Circuit Breaker } \\ \text { XML } & \text { eXtensible Markup Language } \\ & \end{array}$




\section{SUMÁRIO}

INTRODUÇÃO

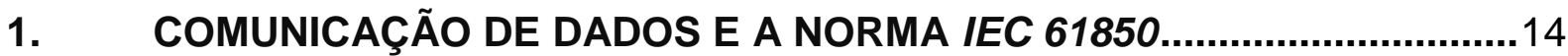

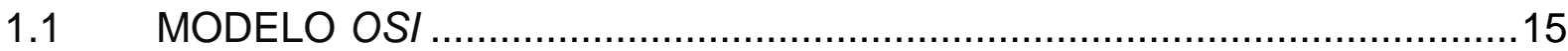

1.2 MODELO DE DADOS SEGUNDO A NORMA IEC $61850 \ldots \ldots \ldots \ldots \ldots \ldots \ldots \ldots \ldots . . . . . . . . . . . . .18$

1.3 LINGUAGEM DE CONFIGURAÇÃO SEGUNDO A NORMA IEC $61850 \ldots . . .21$

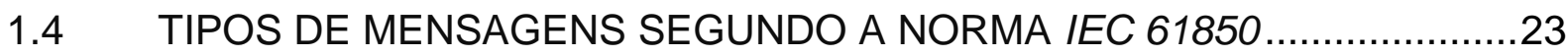

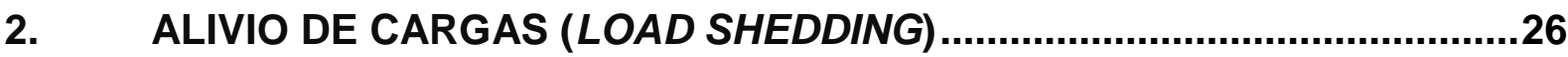

2.1 SISTEMAS ESTÁTICOS DE ALÍVIO DE CARGAS ..................................27

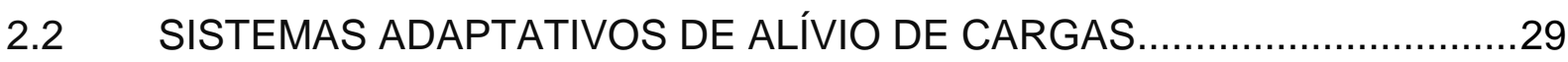

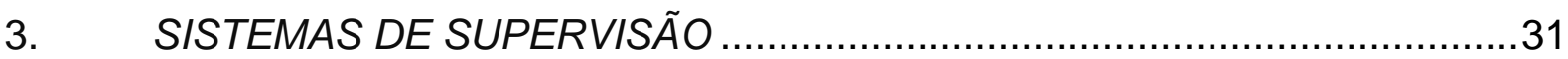

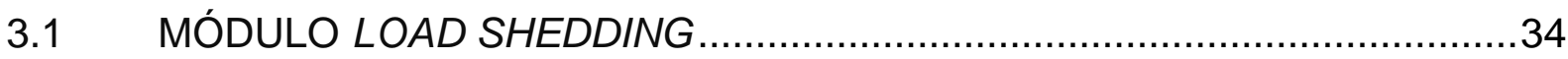

4. SISTEMA AUTOMÁTICO DE ALÍVIO DE CARGA PROPOSTO ..................39

4.1 FUNCIONAMENTO DO SISTEMA DE ALÍVIO DE CARGAS PROPOSTO.40

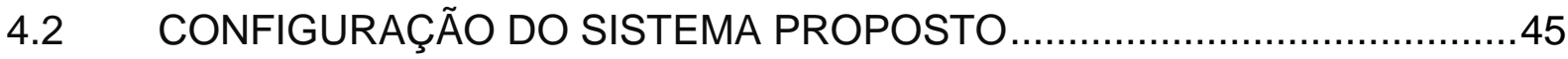

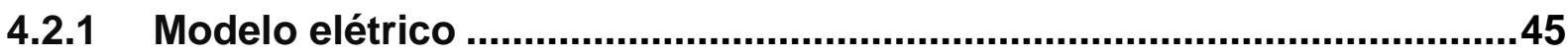

4.2.2 Comunicação do supervisório com IED's ..............................................46

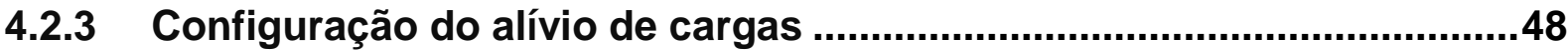

4.3 DEMONSTRAÇÃO DO SISTEMA PROPOSTO …..................................52

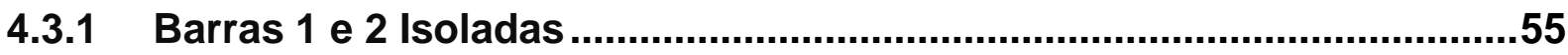

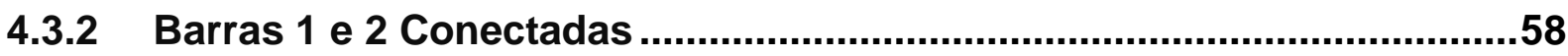

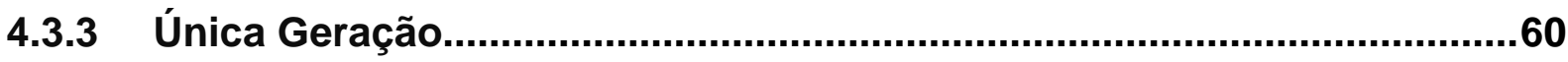

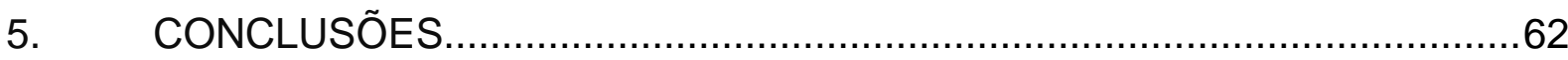

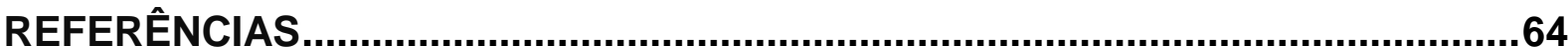




\section{INTRODUÇÃO}

Atualmente, algumas indústrias utilizam um sistema misto para geração de energia, ou seja, suas cargas são alimentadas por processo de geração próprio (co-geração) complementado com suprimento pelo sistema elétrico regional (concessionária). Fatalmente, podem ocorrer emergências no suprimento oriundo da concessionária, o que contribui para interrupções do fornecimento da energia elétrica complementar. Nestas ocasiões, se a quantidade de cargas ligadas permanece inalterada, ocorre um desequilíbrio na relação entre a geração e o consumo de energia pelo circuito elétrico da indústria, o que pode culminar com o colapso do seu sistema e com a danificação dos seus geradores. Com o objetivo de minimizar o impacto deste desequilíbrio na indústria, algumas técnicas de alívio de cargas são comumente utilizadas. Tais técnicas efetuam um desligamento de determinadas cargas com o objetivo de restabelecer o equilíbrio entre o consumo e a geração de energia remanescente.

A maioria dos sistemas de alívio de cargas instalados nas indústrias utiliza controladores lógicos programáveis (CLP's) e relés de frequência para controlar lógicas de desligamento de cargas. Estas técnicas são baseadas em sistemas estáticos, ou seja, consideram um número fixo de cargas que são agrupadas em estágios conforme seus graus de importância para o funcionamento da indústria. Estas lógicas são disparadas somente após a ocorrência de interrupções no fornecimento de energia elétrica e por isso, frequentemente, demandam desligamentos adicionais para o restabelecimento do equilíbrio do circuito. Além disso, o tempo de processamento demandado pela lógica, disparada após a ocorrência do desequilíbrio entre a geração e o consumo, faz com que os geradores da indústria percam parte de sua inércia e tenham sua vida útil comprometida.

Com o objetivo de se contornar as limitações dos sistemas estáticos de alívio de cargas e fundamentando-se nas evoluções dos dispositivos eletrônicos inteligentes (IED's), das redes de comunicação, dos softwares de supervisão e com as padronizações trazidas pela norma IEC 61850, torna-se possível a proposição de um sistema adaptativo de alívio de cargas. Este sistema oferece recursos para se adequar ao cenário elétrico atual e promover uma ação preditiva que não desligue 
um número fixo de cargas, mas sim uma quantidade de cargas cujo somatório é mais próximo do montante de energia que deixará de ser fornecida, caso ocorra interrupção no fornecimento pela concessionária.

Dessa forma, para fundamentar as ferramentas que constituirão as bases utilizadas pelo sistema adaptativo de alívio de cargas, este trabalho efetua uma revisão bibliográfica e esclarece os conceitos sobre redes de comunicação, norma IEC 61850, sistemas de supervisão e técnicas de alívio de cargas.

Com as bases teóricas esclarecidas, o trabalho propõe um sistema adaptativo de alívio de cargas, implementado através da ação conjunta entre um software de supervisão de mercado e relés de proteção, conectados segundo padronizações da norma IEC 61850. O software de supervisão possui um cadastro elétrico correspondente ao diagrama unifilar do circuito, recebe as informações das potências geradas e consumidas e lê os estados dos disjuntores que ligam e desligam a alimentação das cargas da indústria. Através do relacionamento dessas informações, o software é capaz de calcular o panorama do cenário elétrico atual da indústria e simular a ocorrência dos eventos que caracterizam interrupções no fornecimento de energia pela concessionária, antes que o desequilíbrio efetivamente ocorra. O resultado dessas simulações consiste em uma lista de ordens de desligamentos, formada pelo conjunto de disjuntores que serão abertos e provocarão o desligamento de determinadas cargas da indústria. Esta lista de ordens é transferida aos relés de proteção do sistema, antes da real ocorrência do evento simulado pelo algoritmo do software de supervisão, caracterizando sua ação preditiva.

Para promover a abertura dos disjuntores e realizar o desligamento das cargas, os relés de proteção possuem lógicas que levam em consideração, além da ordem enviada pelo sistema de supervisão, o sinal correspondente a real ocorrência da interrupção de energia. Dessa forma, como o sistema de supervisão já efetuou suas simulações e transferiu as ordens de desligamento aos relés de proteção, esses apenas aguardam o recebimento do sinal correspondente à interrupção de fornecimento pela concessionária para promover o alívio de cargas. Como este sinal é transferido entre os relés, através de mensagens rápidas do padrão IEC 61850, o sistema de supervisão não acarreta atrasos na atuação do sistema, que atua em 
intervalos de tempo suficientemente curtos para o restabelecimento entre o equilíbrio entre as potências consumidas e geradas pelo circuito remanescente. 


\section{COMUNICAÇÃO DE DADOS E A NORMA IEC 61850}

Segundo (GURJÃO, CARMO, \& SOUZA, 2006), a comunicação entre diferentes sistemas utiliza um conjunto de regras que define um tipo e a ordem de troca das mensagens. Este conjunto de regras é denominado protocolo de comunicação. $\mathrm{O}$ objetivo principal de um protocolo de comunicação é permitir que sistemas e equipamentos, que possuam arquiteturas internas distintas, apresentem a mesma estrutura lógica de troca de mensagens e assim consigam trocar informações. No entanto, a falta de um modelo de referência, que defina as regras básicas para uma determinada comunicação, implica no surgimento de soluções proprietárias, ou seja, cada fabricante pode definir um protocolo específico para os seus produtos e impedir a comunicação com equipamentos de outros fabricantes. O problema da diversidade de protocolos proprietários ocorre nas redes de comunicação das subestações de energia elétrica, em outras palavras, cada fabricante utiliza o seu protocolo, o que dificulta a interligação entre equipamentos de fabricantes distintos, que pode ser feita através do uso de conversores de protocolos (gateways). No entanto, essa alternativa gera atrasos de comunicação e para sistemas em tempo real, como é o caso da proteção de uma subestação, atrasos na troca de mensagens podem gerar atuações indevidas provocando distúrbios no fornecimento de energia elétrica.

Com o objetivo de obter um padrão único de comunicação entre equipamentos em subestações de energia elétrica, no início dos anos 90, grupos de trabalho do Comitê Técnico TC57 da International Electrotechnical Comission (IEC) foram estabelecidos para preparar um padrão para comunicação de sistemas em subestações. Esse padrão foi denominado IEC 61850 Redes de Comunicação e Sistemas em Subestações (do inglês, IEC 61850 Communication Networks and Systems in Substations).

A norma IEC 61850 utiliza uma linguagem orientada a objetos, divide as funções de proteção em objetos denominados nós lógicos $(L M)$, que comunicam entre si, e permite que o sistema de automação de uma subestação seja uma plataforma aberta, independentemente dos diferentes fabricantes dos equipamentos envolvidos. Dentre os benefícios trazidos pela norma IEC 61850 podem ser citados: 
- Comunicação entre diferentes equipamentos de campo.

- Suporte a funções específicas para proteção elétrica.

- Operação distribuída.

- Redução dos custos de engenharia e comissionamento.

- Maior velocidade na troca de informações.

- Mensagens rápidas e prioritárias, como (Generic Object Oriented Substation Event) GOOSE e (Generic Susbtation State Event) GSSE.

- Envio espontâneo de mensagens (Reports).

- Mensagens enviadas com estampa de tempo.

\subsection{MODELO OSI}

Segundo estudos (Pinheiro, 2004), no início da década de 1980, com o objetivo de facilitar o processo de padronização para conectar equipamentos de diferentes fabricantes, a Organização Internacional de Padronização (ISO - International Standards Organization) estabeleceu um modelo de arquitetura para sistemas abertos, definindo as diretivas genéricas para a construção de redes de computadores, independente de suas tecnologias. Esse modelo foi denominado Open Systems Interconnection (OSI) e serve como base para a implementação de qualquer tipo de rede.

O modelo OSI é um conjunto de padrões para a formação de um modelo de arquitetura de comunicação entre sistemas. Este modelo divide o sistema de comunicação em partes menores denominadas camadas, onde cada camada é uma coleção de funções similares que prestam serviços à camada acima e recebe serviços da camada abaixo. Assim, uma rede de comunicação é dividida em sete camadas hierárquicas, ou seja, cada uma usa as funções da própria camada ou da camada inferior, para esconder a complexidade e transparecer as operações para o usuário, seja ele um programa ou outra camada.

A Figura 1 ilustra as camadas definidas pelo modelo OSI. 


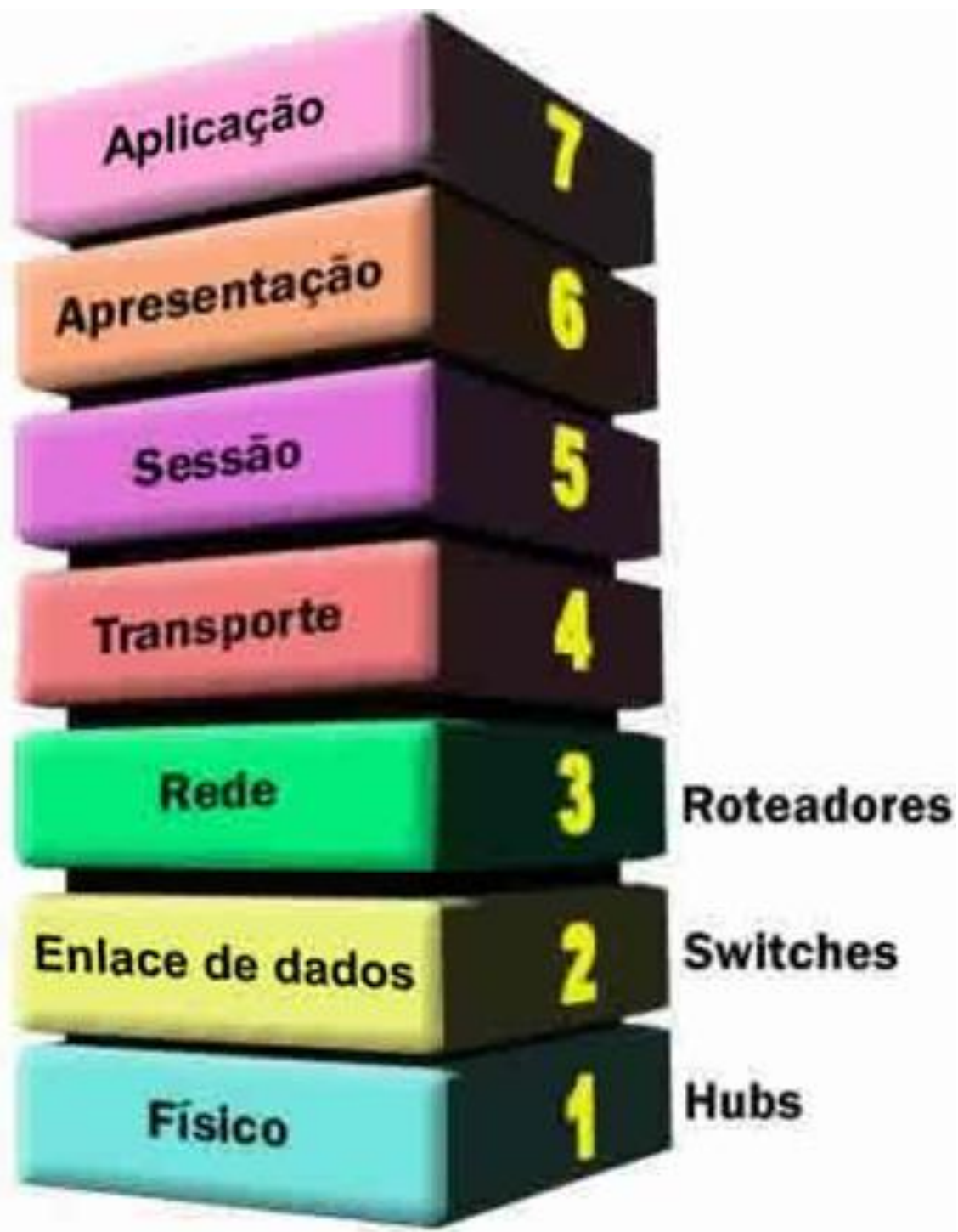

Figura 1 - Modelo OSI (fonte: http://rafaelpinto1995.blogspot.com/2011/02/modelo-osi.html)

- Camada Física

A camada física realiza a codificação e a decodificação dos símbolos e caracteres em sinais elétricos lançados no meio físico. O nível físico tem a função de transmitir uma sequencia de bits através de um canal de comunicação. A função típica desta camada é fazer com que um dado transmitido por uma estação seja entendido pelo receptor. Assim, este nível trabalha com as características mecânicas e elétricas do meio físico, como por exemplo: número de volts que devem representar os níveis lógicos, velocidade máxima da transmissão, transmissão simplex, half duplex ou full duplex, número de pinos do conector, diâmetro dos condutores (PINHEIRO, 2004).

- Camada de Enlace ou Ligação de Dados 
A camada de ligação de dados também é conhecida como camada de enlace ou link de dados. Esta camada detecta e, opcionalmente, corrige erros que possam acontecer no nível físico. Além disso, também estabelece um protocolo de comunicação entre sistemas diretamente conectados (WIKIPÉDIA, 2013).

- Camada de Rede

A camada de rede é responsável pelo endereçamento dos pacotes de rede associando endereços lógicos (IP) em endereços físicos, de forma que os pacotes de rede consigam chegar corretamente ao destino. Essa camada também determina a rota que os pacotes irão seguir para atingir o destino, baseada em fatores como condições de tráfego da rede e prioridades (WIKIPÉDIA, 2013).

- Camada de Transporte

A camada de transporte é responsável por receber os dados enviados pela camada de sessão e segmentá-los para que sejam enviados à camada de rede, que por sua vez, transforma esses segmentos em pacotes. No receptor, a camada de transporte realiza o processo inverso, ou seja, recebe os pacotes da camada de rede e divide em segmentos para enviar à camada de sessão. Isso inclui controle de fluxo, ordenação dos pacotes e a correção de erros, tipicamente enviando para o transmissor uma informação de recebimento, informando que o pacote foi recebido com sucesso (WIKIPÉDIA, 2013).

- Camada de Sessão

A camada de sessão permite que diferentes aplicações definam a forma como será feita a transmissão de dados e estabeleçam uma sessão de comunicação. Esta camada disponibiliza serviços como pontos de controles periódicos a partir dos quais a comunicação pode ser restabelecida em caso de falhas na rede (WIKIPÉDIA, 2013).

- Camada de Apresentação

A Camada de Apresentação, também chamada camada de tradução, realiza a conversão do formato de dados, de forma que eles sejam entendidos por todos os sistemas envolvidos na comunicação, ou seja, através dos serviços desta camada, sistemas de 32 bits podem trocar informações com sistemas 64 bits sem problemas de interpretação (PINHEIRO, 2004).

- Camada de Aplicação 
No topo do modelo OSI está a camada de Aplicação, que corresponde aos programas que serão utilizados para efetuar a interação entre a máquina destinatária e o usuário da aplicação (WIKIPÉDIA, 2013).

\subsection{MODELO DE DADOS SEGUNDO A NORMA IEC 61850}

Segundo (GURJÃO, CARMO, \& SOUZA, 2006), a norma IEC 61850 define e padroniza 0 modelo dos dados que representam os atributos e as funções dos dispositivos físicos de uma subestação ou usina do sistema elétrico. Este modelo é voltado para a orientação ao objeto e utiliza todos os conceitos associados a este tipo de estrutura de dados. 


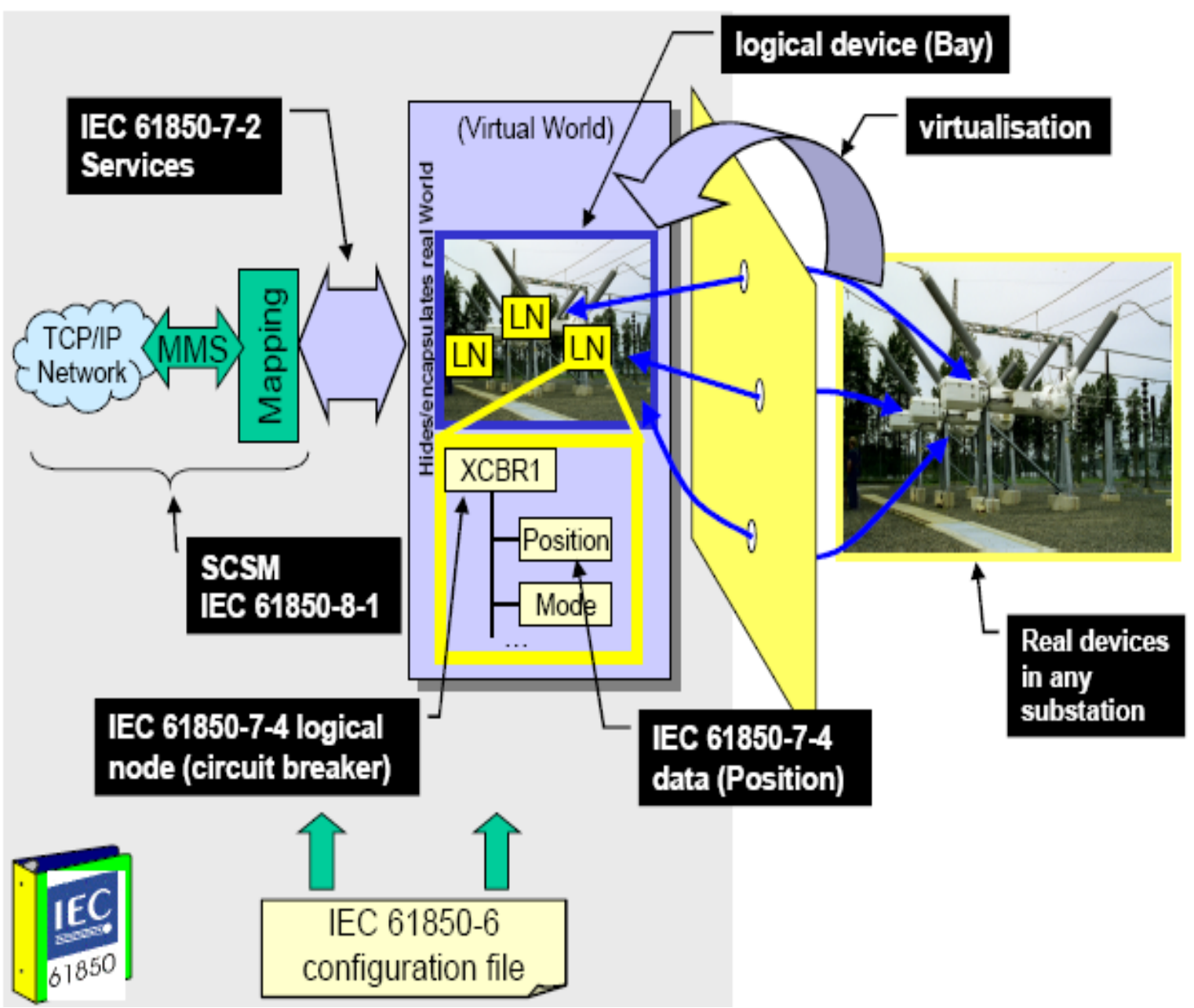

Figura 2 - Modelo de Dados ${ }^{1}$

Conforme ilustrado na Figura 2, cada equipamento do sistema elétrico da subestação (disjuntores, chaves, transformadores, etc.) é representado por um determinado objeto, que se caracteriza como uma instância de uma classe de dados, denominado nó lógico $(L M)$. O conjunto de nós lógicos e suas funções formam um dispositivo lógico (LD). Conforme (Gurjão, Carmo, \& SOUZA, 2006), os nós lógicos contêm uma lista de informações baseadas em sua funcionalidade com os respectivos atributos. Os dados possuem uma semântica bem definida dentro do contexto de sistema de automação de subestações. O nó lógico que representa a função de um disjuntor é denominado Circuit Breaker $(X C B R)$. Um dos atributos associados ao nó lógico $X C B R$, por exemplo, é POS (posição) que é diferente de um

\footnotetext{
${ }^{1}$ Figura retirada do treinamento sobre protocolos elétricos, ministrado pelo instrutor Marcelo Salvador, da empresa Elipse Software, em Agosto de 2008.
} 
simples ponto de estado do disjuntor, pois POS tem vários atributos que são categorizados como:

- Controle (estado, medidas/valores medidos, configuração);

- Substituição;

- Configuração, descrição e extensão.

A Figura 3 ilustra a estrutura hierárquica do modelo de dados interno ao dispositivo físico.

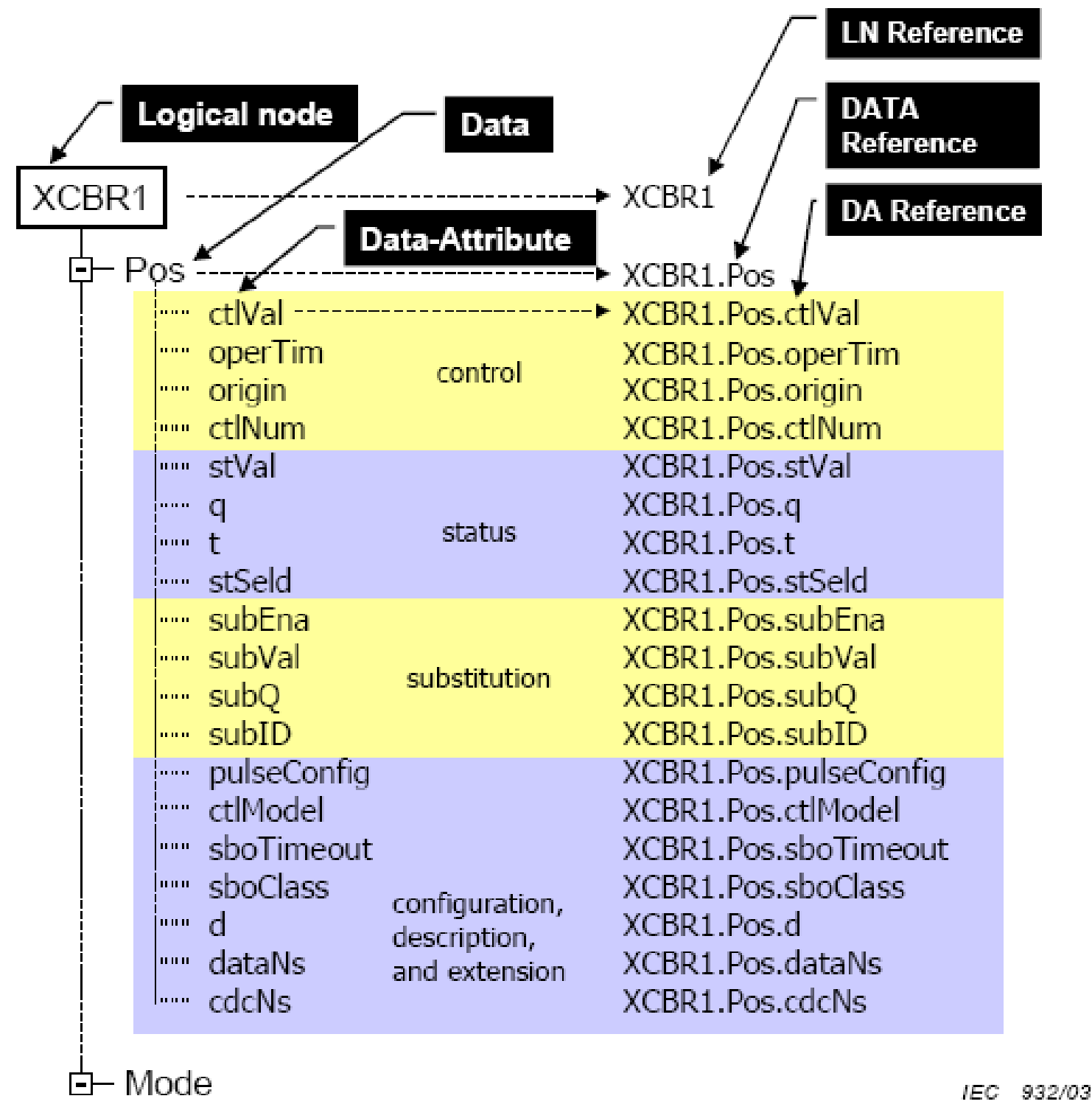

Figura 3 - Atributos de um nó lógico²

\footnotetext{
${ }^{2}$ Figura retirada do treinamento sobre protocolos elétricos, ministrado pelo instrutor Marcelo Salvador, da empresa Elipse Software, em Agosto de 2008.
} 
Dessa forma, o atributo Pos.ctlVal representa um controle e pode ser um comando de abertura ou fechamento de um disjuntor. Já o Pos.stVal representa a indicação do estado atual do disjuntor podendo assumir os seguintes estados: transição, aberto, fechado ou defeito.

Finalmente, o dispositivo eletrônico inteligente (IED) é composto por um hardware e pelo software que modela o conjunto dos nós lógicos e implementa as suas funções de proteção e controle da subestação.

\subsection{LINGUAGEM DE CONFIGURAÇÃO SEGUNDO A NORMA IEC 61850}

Conforme estudos (GURJÃO, CARMO, \& SOUZA, 2006), a norma IEC 61850 define uma linguagem de programação para configuração do sistema de automação de subestações. Esta linguagem é denominada Substation Configuration Language (SCL), é baseada na estrutura eXtensible Markup Language (XML) e permite que os modelos de funções de proteção e de equipamentos de uma subestação sejam padronizados.

Segundo (PEREIRA, ABBOUD, PELLIZZONI, ZANIRATO, \& CACERES, 2009), as diversas possibilidades e funcionalidades disponíveis em um determinado IED são representadas na linguagem SCL através do arquivo IED Capability Description $(I C D)$, fornecido pelo fabricante. A especificação do sistema de automação da subestação, transcrita em linguagem SCL, constitui 0 arquivo Substation Specification Description (SSD). Este arquivo, juntamente com os arquivos ICD dos diversos IED's configurados através do emprego de uma ferramenta de engenharia adequada, de modo a atender aos requisitos especificados, origina o arquivo System Configuration Description (SCD). Adicionalmente, o arquivo de cada IED, depois de configurado para um projeto específico, passa a ser denominado arquivo Configured IED Description (CID) daquele IED.

Dessa forma, estes arquivos contêm os atributos da subestação, das relações dos equipamentos de manobras, da funcionalidade dos IED's e de todos os serviços de 
comunicação. Os arquivos são utilizados para a troca de informações de configuração entre equipamentos de diferentes fabricantes.

A Figura 4 ilustra a arquitetura de um sistema de configuração utilizando a linguagem SCL.

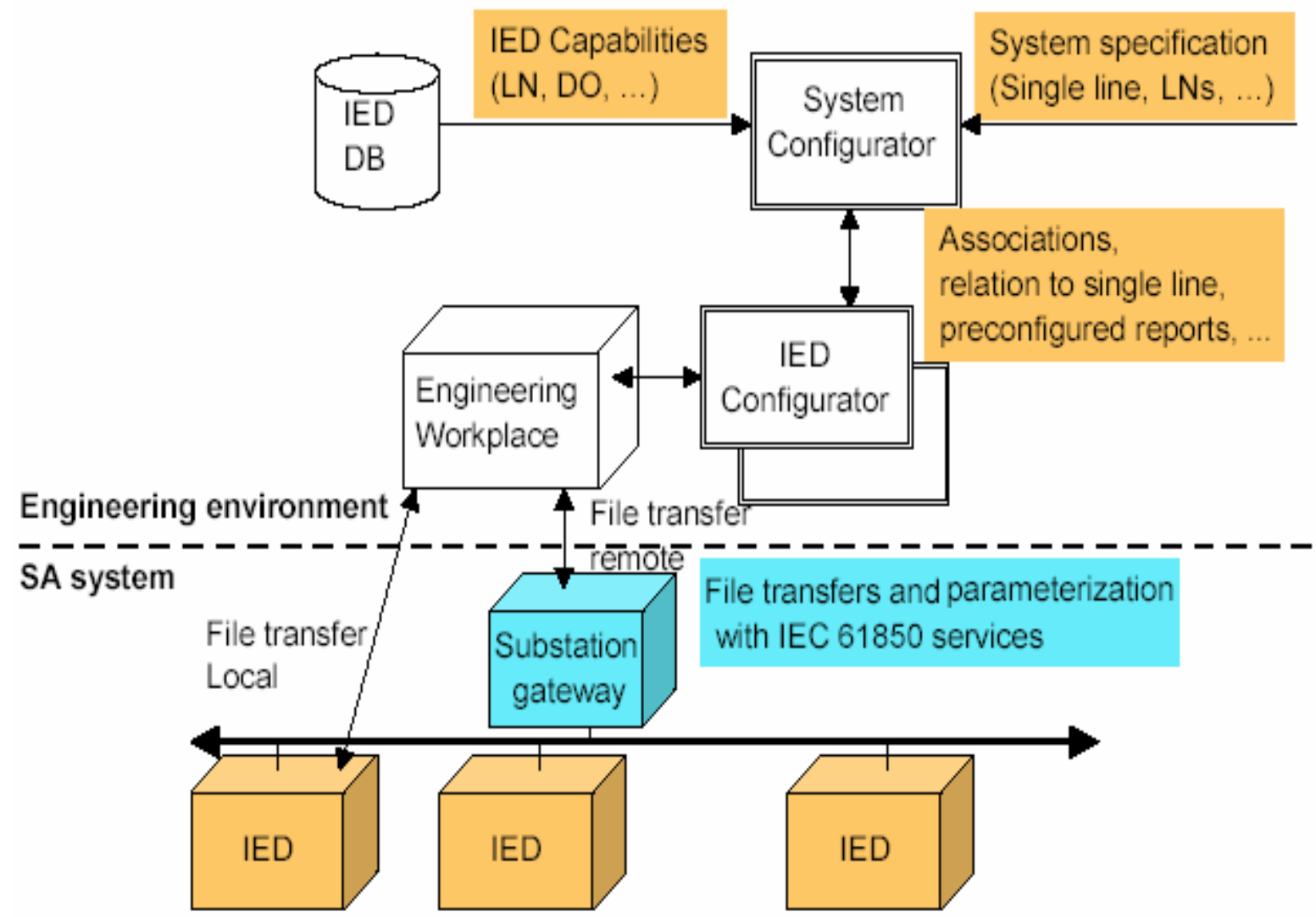

Figura 4 - Arquitetura Linguagens (GURJÃO, CARMO, \& SOUZA, 2006)

Na figura acima, visualiza-se uma estação de engenharia que executa os seguintes aplicativos:

- Configurador do sistema que por meio do arquivo $S S D$ realiza as operações necessárias para configurar o sistema.

- Configurador de IED que utiliza o arquivo ICD para configurar os IED's.

- Gerenciamento de configuração transfere através do gateway os arquivos contendo a configuração para os IED's. 


\subsection{TIPOS DE MENSAGENS SEGUNDO A NORMA IEC 61850}

Estudos (Pereira, Abboud, Pellizzoni, Zanirato, \& Caceres, 2009) mostram que a norma IEC 61850 define três níveis hierárquicos de comunicação para suas aplicações:

- Nível estação: onde se encontram os sistemas gateways, softwares supervisórios (SCADA), centros de operação.

- Nível bay: onde se encontram os relés de proteção ou IED's da subestação.

- Nível processo: onde se encontram os equipamentos da subestação como transformadores, chaves, disjuntores, etc.

Nivel de Estação

\section{Controle} Gateway

\section{Nivel de Bay}

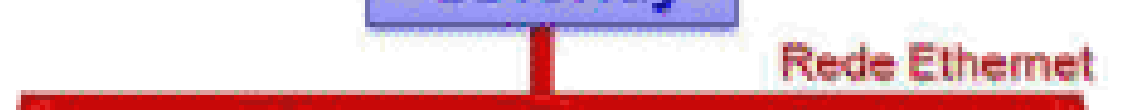

\section{Nivel de Processo}

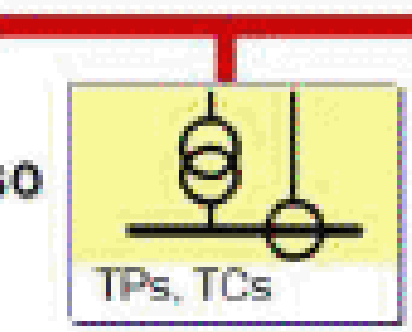

\section{IED}

Controlee

proteçăo

\section{IED}

Controle e

proteçào

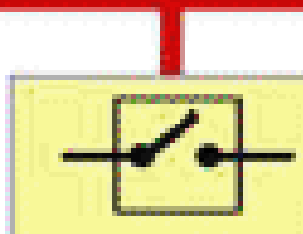

Chaves, DJs

Figura 5 - Níveis Hierárquicos (PAULINO, SIQUEIRA, \& CARMO, 2010)

As comunicações são classificadas de acordo com o fluxo de informações como:

- Comunicação Vertical: são realizadas entre níveis hierárquicos diferentes.

- Comunicação Horizontal: ocorrem dentro do mesmo nível.

Por um lado, segundo (PEREIRA, ABBOUD, PELLIZZONI, ZANIRATO, \& CACERES, 2009), a troca de informações entre um software supervisório e os relés de proteção de uma subestação é um exemplo de comunicação vertical. As informações são transferidas no modo cliente-servidor, onde o supervisório é o 
cliente e o IED é o servidor de dados, ou seja, as informações são fornecidas pelo servidor mediante solicitação do cliente ou espontaneamente pelo servidor, a partir de eventos pré-definidos na configuração do relé (Reports). Este modo de transmissão utiliza todas as camadas do modelo OSI e por isso tem a vantagem de contar com mecanismos responsáveis pela garantia da confiabilidade entre a transmissão e a recepção dos dados. No entanto, como desvantagem as mensagens cliente-servidor têm um atraso inserido pelo processamento em cada camada, e por esse motivo têm um desempenho relativamente lento, com tempos de resposta da ordem de 1 a 2 segundos.

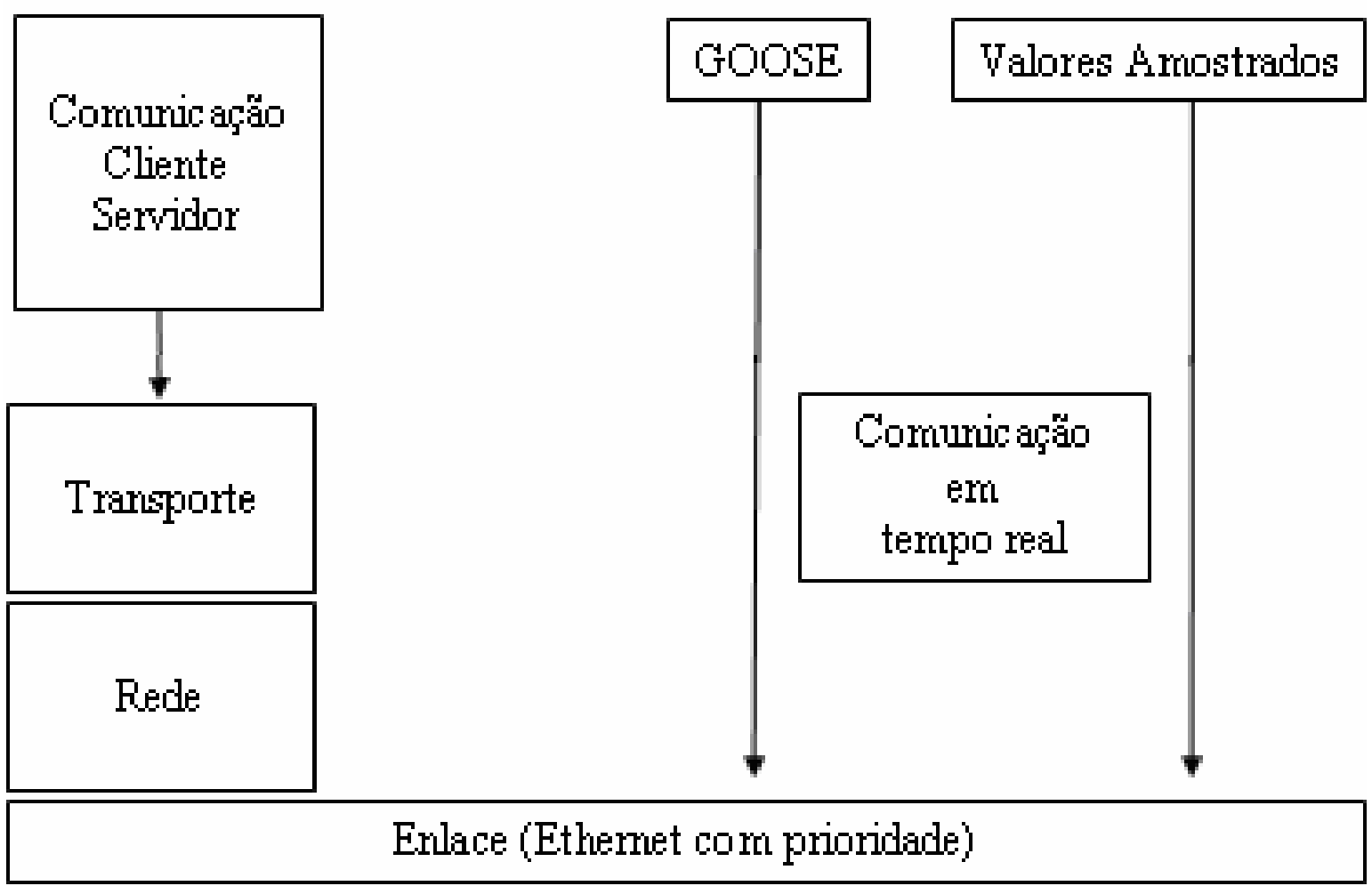

Figura 6 - Estrutura Mensagens IEC 61850 (GURJÃO, CARMO, \& SOUZA, 2006)

Por outro lado, os estudos (PEREIRA, ABBOUD, PELLIZZONI, ZANIRATO, \& CACERES, 2009) mostram que a troca de informações entre os relés de proteção de uma subestação é um exemplo de comunicação horizontal. Come o objetivo de eliminar qualquer tipo de latência no processo de transmissão das mensagens, as informações são trocadas através do modo publisher-subscriber, também conhecido como produtor-consumidor ou editor-assinante. Neste tipo de comunicação não existe nenhum tempo gasto estabelecendo conexão ou negociação para iniciar uma seção de comunicação. $O$ emissor publica as mensagens e os usuários subscritos 
capturam a mensagem que tem interesse. Esta comunicação não depende das camadas do modelo OSI. Como desvantagem não conta com os mecanismos de confirmação de cada camada, ou seja, as mensagens têm que utilizar um esquema de retransmissão especial para alcançar um nível de confiabilidade adequado, que consiste em repetir a mensagem por diversas vezes. A cada nova tentativa, o tempo de espera é dobrado, de modo a minimizar colisões, até atingir um valor máximo, definido como tempo máximo (Tmax - da ordem de segundos). Depois de atingido esse intervalo máximo, a mensagem é repetida indefinidamente, mantendo este último intervalo. Se o envio do sinal é descontinuado, o receptor assume que a conexão foi perdida.

\section{Evento}

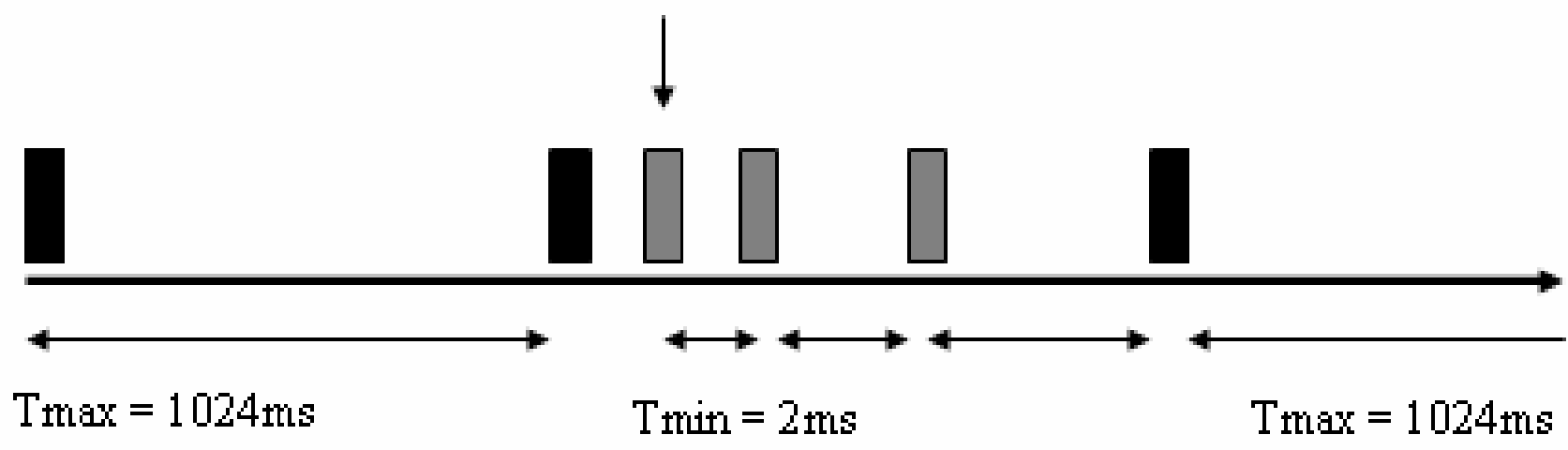

Figura 7 - Envio de Mensagens (GURJÃO, CARMO, \& SOUZA, 2006)

Segundo (PEREIRA, ABBOUD, PELLIZZONI, ZANIRATO, \& CACERES, 2009), como grande vantagem de não utilizar as camadas do modelo OSI, as mensagens da comunicação horizontal são rápidas (alta velocidade) com tempo de transmissão em torno de 4 a 8 ms. As mensagens de alta velocidade são denominadas Generic Substation Events (GSE) e podem ser subdividas em mensagens Generic Object Oriented Substation Event (GOSSE) e mensagens Generic Susbtation State Event (GSSE). A diferença entre ambas é que, nas mensagens GOOSE, a informação é configurável e utiliza um bloco de dados (Data Set). As mensagens GSSE somente suportam uma estrutura fixa de informação de estado, a qual é publicada e disponibilizada na rede. As mensagens GSE são utilizadas para transportarem informações com restrição crítica de tempo como atuação de proteções (Trip), bloqueios, abertura de disjuntores e chaves. 


\section{ALIVIO DE CARGAS (LOAD SHEDDING)}

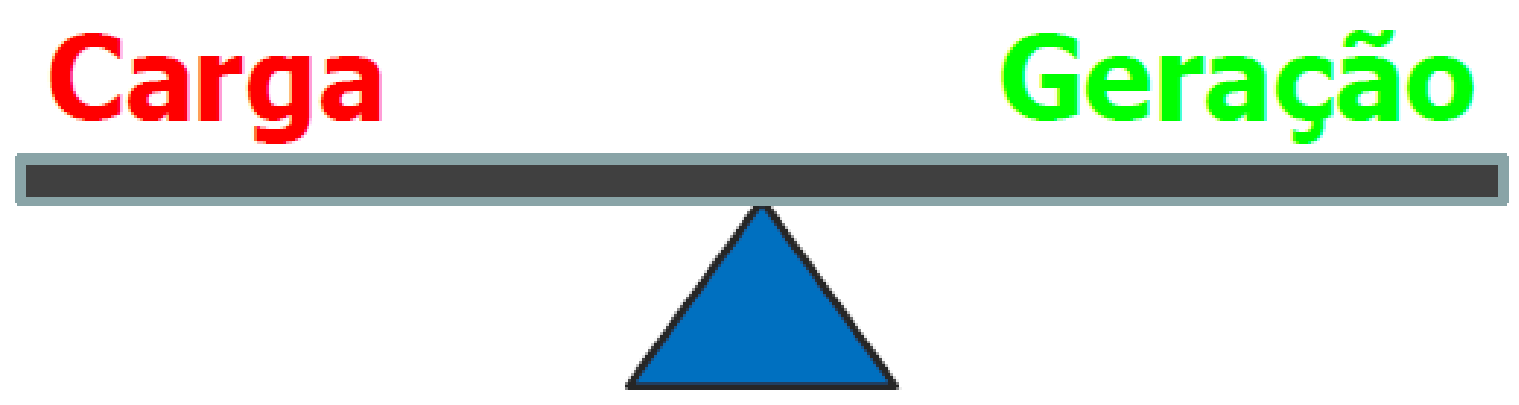

Figura 8 - Equilíbrio de energia (MUSARRA \& JARDINI, 2012)

Atualmente, algumas indústrias apresentam um sistema misto para a geração de energia, isto é, suas cargas são alimentadas por processo de geração próprio (cogeração) complementado com suprimento pelo sistema elétrico regional (concessionária). Assim, o sistema de potência em condições estáveis de operação, com frequência nominal, deve apresentar um equilíbrio entre as potências geradas e consumidas.

No entanto, podem ocorrer situações emergenciais na concessionária que provocam a perda da alimentação complementar pela rede supridora e consequentemente ocasionam um desequilíbrio entre as potências geradas e consumidas dentro do ambiente industrial. Nestes casos, a remoção rápida e seletiva de algumas cargas pode possibilitar que o sistema elétrico da indústria recupere o equilíbrio de potência, evitando assim um desligamento de todas as cargas e a danificação das unidades geradoras remanescentes na indústria. Estudos (CARVALHO, 2010) denominam este tipo de filosofia como Esquemas de Alivio, Rejeição ou Descarte de Cargas, ou do inglês Load Shedding, sendo uma tentativa em restabelecer o balanço de potência entre a geração e o consumo.

Esquemas de alívio de cargas devem cumprir os seguintes princípios básicos:

- Prover segurança contra disparos indevidos.

- Desligar o menor número de cargas possível.

- Obedecer às prioridades das cargas a permanecerem ligadas.

- Atuar em intervalo de tempo suficiente para restabelecer o equilíbrio. 


\subsection{SISTEMAS ESTÁTICOS DE ALÍVIO DE CARGAS}

Em uma indústria com sistema misto para geração de energia, quando acontece um desequilíbrio entre as potências geradas e consumidas no circuito, ocorre uma variação da frequência do seu sistema elétrico. Dessa maneira, segundo (Carvalho, 2010), a perda da capacidade de geração de energia, ocasionada pela interrupção no fornecimento de energia pela concessionária, provoca a queda na frequência do sistema.

Devido a este comportamento de queda no valor da frequência mediante a ocorrência de interrupção no fornecimento de energia pela concessionária, atualmente, são utilizadas técnicas baseadas em relés de frequência e controladores lógicos programáveis para a realização do controle dos sistemas de alívio de carga em ambiente industrial.

Normalmente, estas técnicas utilizam lógicas internas que consideram o sistema formado por um número fixo de cargas, que são divididas e agrupadas em diversos estágios de desligamento. Cada estágio possui uma quantidade fixa de cargas e uma prioridade pré-definida conforme a importância dessas cargas para o funcionamento da indústria. Além disso, cada estágio possui um ajuste de frequência do sistema, a partir do qual o seu conjunto de cargas é desligado, ou seja, quando ela atinge o valor correspondente àquele ajustado no estágio, o seu conjunto de cargas é desligado.

Seguindo este princípio, após a ocorrência da perda do suprimento complementar de energia pela concessionária, a frequência do circuito elétrico da indústria sofre uma queda no seu valor. Assim, a lógica de controle do sistema estático de alívio de cargas monitora o valor da frequência e quando esta se iguala ao limite ajustado no primeiro estágio de alívio, o CLP ou o relé de frequência, através de suas saídas digitais, envia as ordens de abertura aos disjuntores responsáveis pelos desligamentos, provocando o corte do primeiro estágio de cargas. Dessa forma, se o valor da frequência do circuito continua caindo, a lógica ordena o corte de cargas dos estágios seguintes, conforme os valores dos ajustes de frequência. O objetivo é desligar, primeiramente, as cargas de serviços não prioritários, passando-se então 
para o desligamento de partes do processo que não tragam grandes impactos, até que estágios vitais de produção comecem a ser desligados. Este processo é repetido até que o sistema restabeleça o equilíbrio entre as potências geradas e consumidas.

Este funcionamento é ilustrado pela Figura 9.

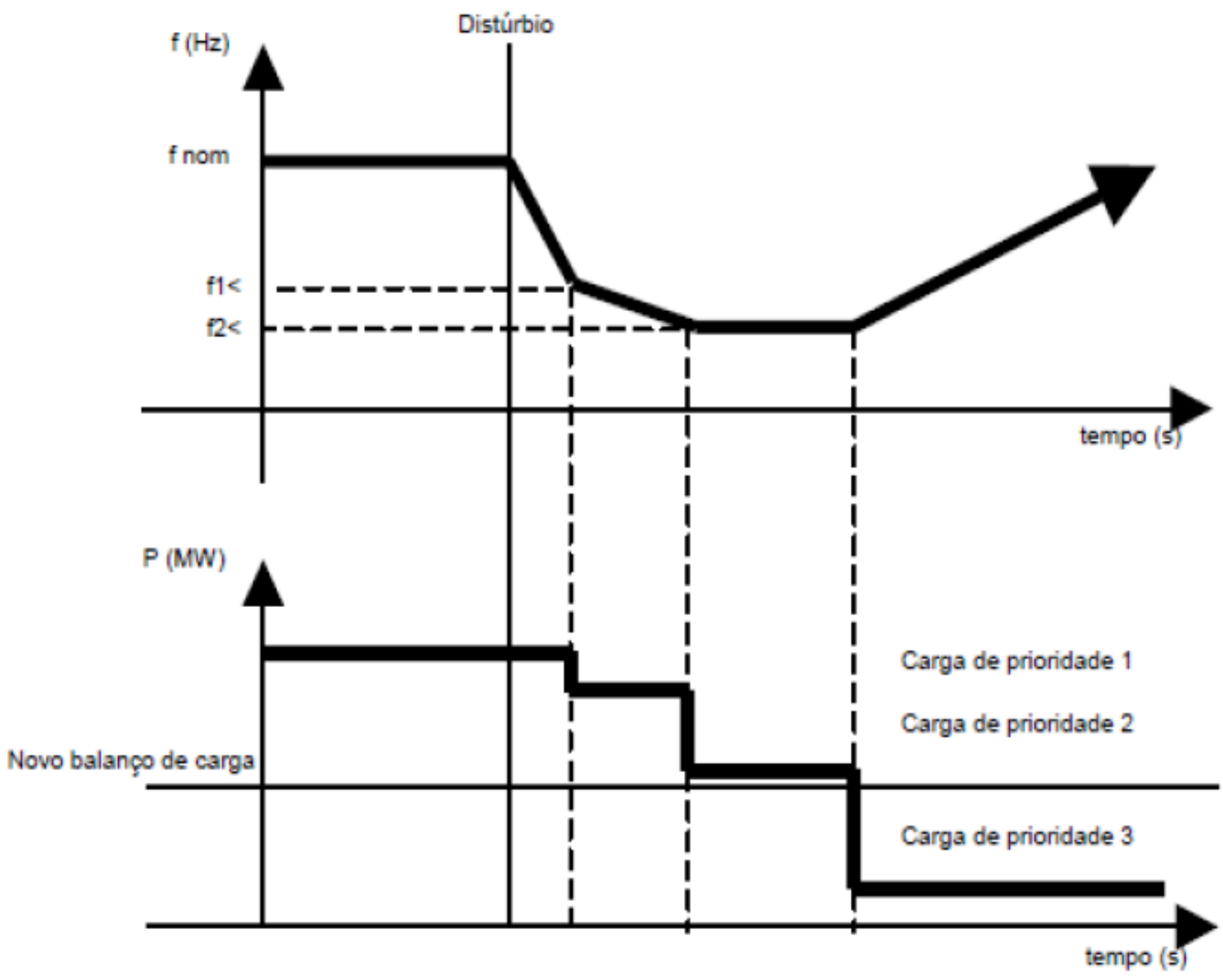

Figura 9 - Descarte Estático de Cargas (CARVALHO, 2010)

No entanto, estudos (CARVALHO, 2010) mostram que os sistemas estáticos de alívio de cargas apresentam as seguintes limitações:

- A sua lógica atua somente após a ocorrência do desequilíbrio entre a potência gerada e consumida, o que provoca a necessidade de desligamentos adicionais para que o sistema retorne ao equilíbrio.

- Como a lógica é disparada após a ocorrência do desequilíbrio, o tempo para seu processamento e para o envio das ordens de desligamento aos 
disjuntores provoca atrasos na atuação do sistema, o que contribui para a perda da velocidade e da inércia dos geradores da indústria, que têm sua estabilidade e vida útil comprometidas.

- Os algoritmos estáticos de alívio de cargas levam em consideração um número fixo de cargas, prioridades e estágios. Isso dificulta a expansão e a alteração das lógicas de alívio de cargas.

- Os algoritmos são baseados em lógicas customizadas para a indústria o que dificulta a padronização e a organização dos sistemas.

\subsection{SISTEMAS ADAPTATIVOS DE ALÍVIO DE CARGAS}

Uma alternativa para se contornar as limitações dos sistemas estáticos para desligamento de cargas são os esquemas adaptativos de alívio de carga. Estes esquemas não desligam uma quantidade fixa de estágios de cargas, mas sim uma quantidade de cargas cujo somatório é mais próximo do montante de energia que deixará de ser fornecido caso ocorra uma interrupção no fornecimento pela concessionária.

Os sistemas adaptativos se baseiam em uma ação conjunta entre software e IED's para controlar a lógica de alívio de cargas. Por um lado, o software de controle recebe as informações das potências geradas e consumidas do circuito, assim como os estados dos disjuntores que alimentam as cargas da indústria. Com base nessas informações o software executa um algoritmo de fluxo de potência e estabelece as condições atuais do sistema elétrico, ou seja, o sistema define o cenário elétrico atualmente vigente na indústria. Em seguida, um algoritmo de alívio de cargas é executado com o objetivo de simular a ocorrência de eventos que caracterizam a perda do sistema supridor de energia pela concessionária. O resultado dessas simulações é uma lista formada pelo conjunto de disjuntores que serão abertos e provocarão o desligamento de determinadas cargas, respeitando-se as prioridades de cada carga para a indústria. Esta lista é transferida aos relés de proteção do 
sistema antes da real ocorrência do evento simulado pelo algoritmo do software de supervisão, caracterizando sua ação preditiva.

Por outro lado, para promover a abertura dos disjuntores e realizar o desligamento das cargas, os relés de proteção possuem lógicas que consideram além da ordem enviada pelo sistema de supervisão, o sinal correspondente a real ocorrência da interrupção de energia. Dessa forma, como o sistema de supervisão já efetuou suas simulações e transferiu as ordens de desligamento aos relés de proteção, esses apenas aguardam o recebimento do sinal correspondente à interrupção de fornecimento pela concessionária para promover o alívio de cargas. Como este sinal é transferido entre os relés, através de mensagens específicas, o sistema de supervisão não acarreta atrasos na atuação do sistema, que atua em intervalos de tempo suficientes para o restabelecimento entre o equilíbrio e as potências consumidas, geradas pelo circuito remanescente.

Em comparação ao esquema tradicional de rejeição de cargas, estudos (Carvalho, 2010) mostram que a rejeição adaptativa possui as seguintes vantagens:

- Como o cenário elétrico é constantemente atualizado pelo software de controle, há uma maior capacidade de desligar cargas cujo somatório é mais próximo da quantidade real necessária para se atingir o nível de estabilidade no momento da ocorrência do evento de perda de geração.

- O esquema permite a alteração da quantidade e das prioridades de cargas em qualquer momento.

- Ação preditiva, pois como o algoritmo calcula constantemente o cenário elétrico atual e simula a ocorrência dos eventos de perda de geração, a tabela dinâmica, com as informações de quais cargas devem ser desligadas, é obtida antes da ocorrência do desequilíbrio de potências.

- Como o software de controle não acarreta atrasos na execução das lógicas para desligamento, a ação do sistema ocorre em tempo suficiente para restabelecer o equilíbrio do sistema antes que geradores percam suas inércias. 


\section{SISTEMAS DE SUPERVISÃO}

Os sistemas de supervisão são softwares baseados em telas sinóticas, desenvolvidas através de interface gráfica, para monitorar e supervisionar processos automatizados.

Geralmente, estes sistemas são executados em computadores ou Interface homem máquina (IHM) que se conectam fisicamente a equipamentos como CLP's, Unidades terminais remotas (UTR's), IED's, medidores de energia, através de canais seriais (RS-232, RS-485), Ethernet (TCP-IP, UDP-IP), rádio, GPRS, etc. A comunicação lógica é estabelecida através de módulos denominados drivers, que implementam protocolos específicos para permitir a correta troca de informações entre os equipamentos e os softwares. Dessa forma, por um lado, os sistemas de supervisão são capazes de receber informações provenientes dos controladores de um determinado processo (entradas). Por outro lado, estes softwares permitem que usuários enviem ordens de comando (saídas) para os equipamentos permitindo a execução de determinadas manobras de processo. Este conjunto de dados de entradas e saídas formam a base de dados do software supervisório e representam as informações de um determinado processo e que devem ser reportadas aos seus usuários.

Através de recursos gráficos e de filosofia orientada a objetos, estes softwares permitem que informações sejam inseridas em telas que possuem diagramas sinóticos do processo supervisionado, ou seja, através de janelas intuitivas os usuários podem acompanhar os valores de variáveis relevantes ao comportamento do sistema e interagir com ele através do envio de comandos de operação.

Além disso, os softwares de supervisão possuem recursos para informar aos seus usuários sobre a ocorrência de alarmes no funcionamento de um processo, ou seja, através de recursos gráficos e sonoros o sistema mantém os usuários sempre atualizados sobre as condições de anormalidade de um processo monitorado.

Finalmente, os softwares de supervisão contam com recursos para permitir a geração de relatórios sobre o processo, ou seja, o sistema gera diagnósticos sobre as ocorrências de alarmes e a variação de grandezas analógicas (tendências). Estes 
relatórios são exportados para um formato amigável e externo ao software de supervisão.

Atualmente, existem inúmeros softwares de supervisão comercializados em todo mundo. Os principais sistemas internacionais são Wincc e PowerCC (Siemens), RSView (Allen Bradley), iFix (GE), Intouch (Wondeware), Power SCADA (Schneider). Também existem algumas plataformas nacionais como SCADABr, Citect, E3 e Power (Elipse).

Para implementar um sistema adaptativo de alívio de cargas baseado em um sistema de supervisão, é necessário que o software, além das funcionalidades descritas anteriormente, possua módulos e modelos matemáticos que executem algoritmos específicos para a simulação do cenário elétrico e pré-disponibilização do desligamento de cargas.

Dentre os softwares de supervisão disponíveis no mercado, aquele que melhor combina as funcionalidades de um sistema de supervisão com módulos elétricos capazes de executar um algoritmo adaptativo de alívio de cargas é a plataforma Elipse Power, desenvolvida pela Elipse Software. ${ }^{3}$

Segundo (Elipse, Manual do Elipse POWER, 2013), este software é uma ferramenta de desenvolvimento de aplicações de supervisão, controle e análise de sistemas de energia elétrica. O software é uma plataforma para supervisão e controle voltada para operação em rede e aplicações distribuídas concebidas através de orientação a objetos. Possui drivers para trocar informações com relés de proteção através de enlace Ethernet TCP/IP e protocolo de comunicação IEC 61850. Os módulos e algoritmos do software são executados a partir de um modelo elétrico que descreve o diagrama unifilar do sistema supervisionado. Todos os equipamentos de campo (chaves, disjuntores, transformadores) são modelados através de objetos do software, representando a estrutura do sistema. Baseado nesta modelagem elétrica, o Elipse Power executa módulos matemáticos de apoio à operação do sistema. Estes módulos interagem, em tempo real, diretamente com a aplicação de supervisão, buscando informações do cenário atual e retornando o resultado de

\footnotetext{
${ }^{3}$ A capacidade de o software integrar o seu módulo SCADA e os módulos elétricos como fluxo de potência, processador topológico e alívio de cargas foram fatores decisivos para a tomada da decisão.
} 
cada um destes módulos de analise elétricos. Os principais módulos elétricos do software são os seguintes:

- Processador Topológico: a partir das informações da conectividade entre os equipamentos e dos estados de chaves e disjuntores, o software retorna os barramentos energizados ou desenergizados e identifica as ilhas elétricas do sistema.

- Fluxo de Potência: a partir de informações do processador topológico e das entradas elétricas (impedâncias, capacitâncias, tensões de geradores, potências de carga), o software retorna os valores de tensão de barras e potências em equipamentos.

- Load Shedding: responsável pela lógica adaptativa de análise de desequilíbrio de potência e desligamento de cargas do sistema elétrico. 


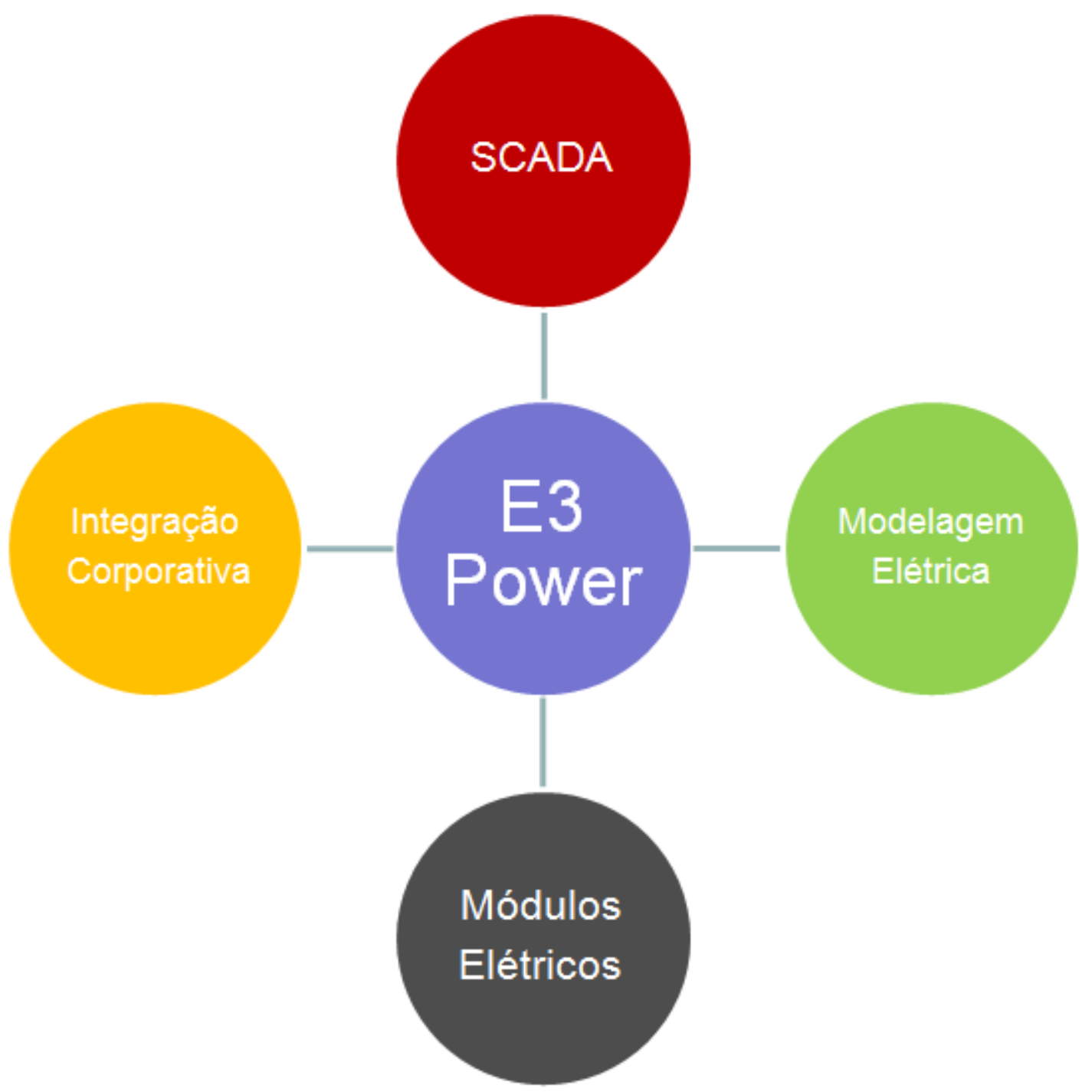

Figura 10 - Estrutura Elipse Power (ELIPSE, MANUAL DO ELIPSE POWER, 2013)

\subsection{MÓDULO LOAD SHEDDING}

O módulo Load Shedding do software de supervisão Elipse Power é aplicável para indústrias que apresentam um sistema misto de geração de energia, e, portanto, necessitam de lógicas de alívio de cargas para garantir o equilíbrio entre as potências geradas e consumidas no circuito, diante de possíveis distúrbios no fornecimento de energia pela concessionária.

Primeiramente, o sistema de alívio de cargas recebe as informações sobre as potências geradas e consumidas no circuito, além dos estados de disjuntores que 
ligam e desligam a alimentação de cargas, através da comunicação com IED's, segundo padrões da norma IEC 61850. Além disso, o software efetua a leitura das prioridades de cada carga da indústria, ou seja, através de telas gráficas o usuário do sistema informa sobre a importância de cada carga para o funcionamento da indústria.

Em seguida, o sistema efetua a leitura de um modelo elétrico, que possui os equipamentos e as conexões correspondentes ao diagrama unifilar do circuito da indústria. De posse das informações provenientes dos IED's e do modelo elétrico do sistema, o módulo Load Shedding constrói o cenário elétrico atual do sistema, através de cálculos de fluxo de potência.

A próxima tarefa executada pelo módulo é efetuar a leitura dos possíveis eventos que caracterizam distúrbios no sistema de geração de energia, ou seja, o software identifica os potenciais eventos que podem ocasionar perda na alimentação, e podem contribuir para desequilíbrios entre a geração e o consumo de energia no circuito desta indústria. Exemplos: abertura do disjuntor que faz interligação entre o sistema supridor e entrada da indústria, abertura do disjuntor que interliga um gerador ao alimentador da indústria, etc. Estes eventos são cadastrados pelo usuário do software durante a configuração do sistema.

Com a lista dos possíveis eventos causadores de distúrbio na geração de energia, o módulo de alívio de cargas simula a ocorrência de cada evento no cenário atual do sistema. Nesta etapa, são utilizados os módulos de análise topológica e fluxo de potências para simulação dos efeitos de distúrbios na geração. Com base nas simulações e nas prioridades de cada carga, o módulo gera um conjunto de ordens para o desligamento de uma lista de disjuntores que devem abrir e providenciar o desligamento das cargas, caso os eventos simulados venham a ocorrer. Dessa forma, o módulo destaca-se pela sua ação preditiva, pois antes da ocorrência de um distúrbio na geração, o sistema já dispõe de uma lista com os disjuntores que devem abrir mediante a possível ocorrência dos eventos causadores de desequilíbrio entre a geração e o consumo de energia.

Finalmente, o sistema envia suas ordens de abertura de determinados disjuntores aos IED's, conectados segundo padronizações da norma IEC 61850. Para promover a abertura dos disjuntores e realizar o desligamento das cargas, os IED's devem 
possuir lógicas que levam em consideração, além da ordem enviada pelo algoritmo de alívio de cargas do sistema de supervisão, o sinal correspondente a real ocorrência do evento já simulado pelo software e correspondente a um distúrbio na energia.

Dessa forma, como o sistema de supervisão já efetuou suas simulações e transferiu às ordens de desligamento aos IED's, estes apenas aguardam o recebimento do sinal correspondente ao distúrbio na geração para promover o alívio de cargas. Como este sinal é transferido entre os relés, através de mensagens GOOSE, o sistema de supervisão não acarreta atrasos na atuação do sistema, que atua em intervalos de tempo suficientes para o restabelecimento entre o equilíbrio entre as potências consumidas e geradas pelo circuito remanescente.

Após um intervalo de tempo correspondente ao ciclo de atualização do sistema de supervisão, o módulo de alívio de cargas reinicia seu funcionamento com o objetivo de atualizar o cenário elétrico e os possíveis eventos causadores de desequilíbrio entre a geração e o consumo de energia.

O funcionamento do módulo de alívio de cargas está ilustrado na Figura 11. 


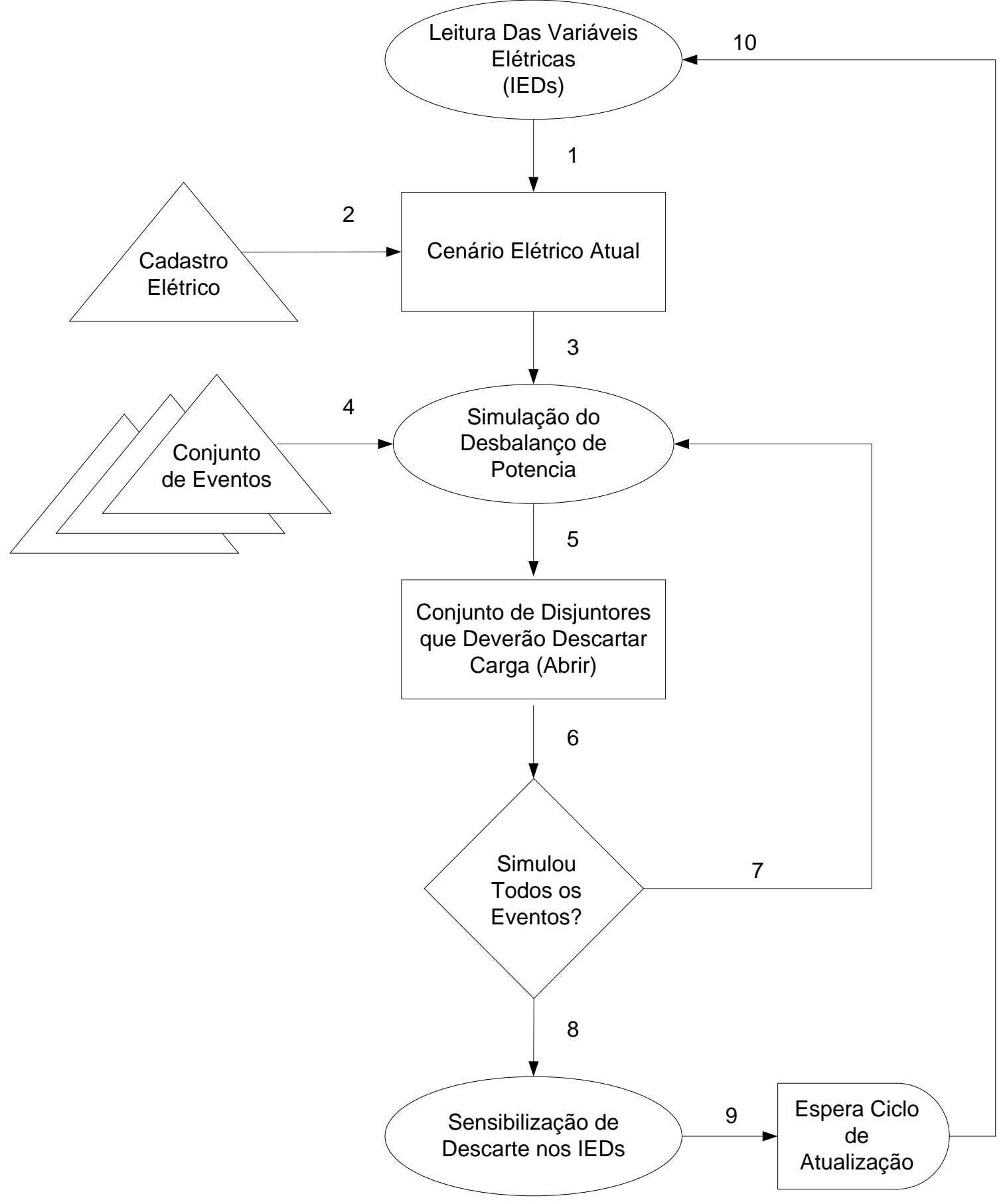

Figura 11 - Algoritmo Descarte Cargas (ELIPSE, MANUAL DO ELIPSE POWER, 2013)

Sendo assim, este módulo apresenta as seguintes características:

- Corrige automaticamente seus cálculos de acordo com a configuração do unifilar do sistema e condições de operação conforme a entrada ou saída de cargas. 
- Possui ação preditiva baseada no cenário elétrico atual, ou seja, prédisponibiliza o desligamento das cargas antes da ocorrência do distúrbio conforme a situação do circuito elétrico no momento.

- Rejeita uma quantidade mínima de carga para manter a estabilidade e frequência nominal.

- Possui uma lista dinâmica de alívio de cargas que é atualizada conforme as mudanças do cenário elétrico e a configuração das prioridades das cargas do sistema.

A grande vantagem deste sistema é o fato do módulo de alívio de cargas não acarretar atrasos no tempo de resposta do sistema e possuir ação preditiva, ou seja, como o módulo Load Shedding simula a ocorrência dos possíveis distúrbios no sistema de geração antes de sua real ocorrência, consegue predispor uma lista de disjuntores que devem ser abertos para o desligamento de cargas, antes que os efeitos do desequilíbrio se propaguem pelo circuito. Sendo assim, no momento da ocorrência do distúrbio, o software não adiciona nenhum atraso na atuação dos dispositivos, que ficam dependentes apenas da troca de mensagens entre si para a detecção do evento de perda na geração, fazendo com que os tempos envolvidos sejam referentes somente a comunicação entre os IED's via mensagens do tipo GOOSE, que podem ocorrer em intervalos de tempos da ordem de 2 a $4 \mathrm{~ms}$, segundo (BULGARELLI, SENGER, FILHO, ZERBINATTI, SANTOS, \& VICECONTI, 2005). 


\section{SISTEMA AUTOMÁTICO DE ALÍVIO DE CARGA PROPOSTO}

Sob o aspecto prático, esta dissertação aplica seu estudo de caso em uma indústria que apresenta sistema misto de geração de energia elétrica. Nesta indústria existem seis cargas de 0,5 MW de ponta, cada uma, alimentadas por um sistema misto formado por dois geradores próprios com potência de $1 \mathrm{MW}$, cada um, e pela alimentação complementar da concessionária, formada por uma rede de $138 \mathrm{kV}$ suprindo $1 \mathrm{MW}$. A Figura 12 representa o diagrama unifilar do sistema elétrico da indústria.

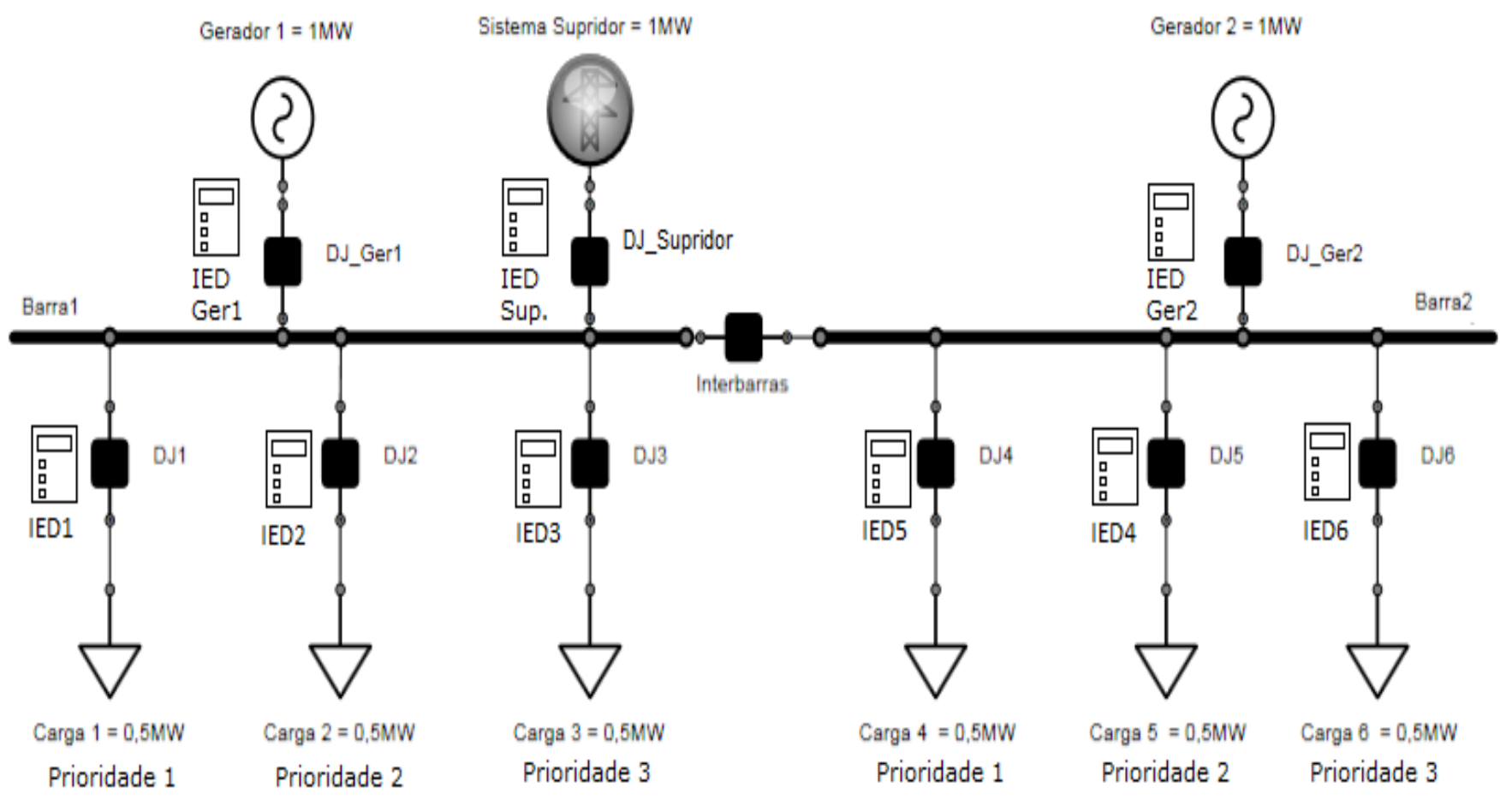

Figura 12 - Sistema elétrico

Para este cenário elétrico será proposta uma solução de alívio de cargas, com o objetivo de restabelecer o equilíbrio entre geração e consumo, caso ocorra a perda do sistema de alimentação complementar da concessionária, caracterizado pela abertura do disjuntor DJ_Supridor.

Após a análise dos conceitos sobre redes de comunicação, norma IEC 61850, sistemas de supervisão e técnicas de alívio de cargas, para solucionar o problema 
do desequilíbrio da indústria, se torna possível à proposição de um sistema baseado no software de supervisão de mercado Elipse Power, que executará seu algoritmo adaptativo de alívio de cargas, e pré-sensibilizará equipamentos inteligentes de campo (IED's), conectados conforme padrões estabelecidos pela norma IEC 61850, para efetuarem o desligamento de algumas cargas da indústria.

\subsection{FUNCIONAMENTO DO SISTEMA DE ALÍVIO DE CARGAS PROPOSTO}

A Figura 13 ilustra a arquitetura utilizada pelo sistema de alívio de cargas proposto.

\section{SISTEMA AUTOMARTICO DE ALIVIO DE CARGAS}

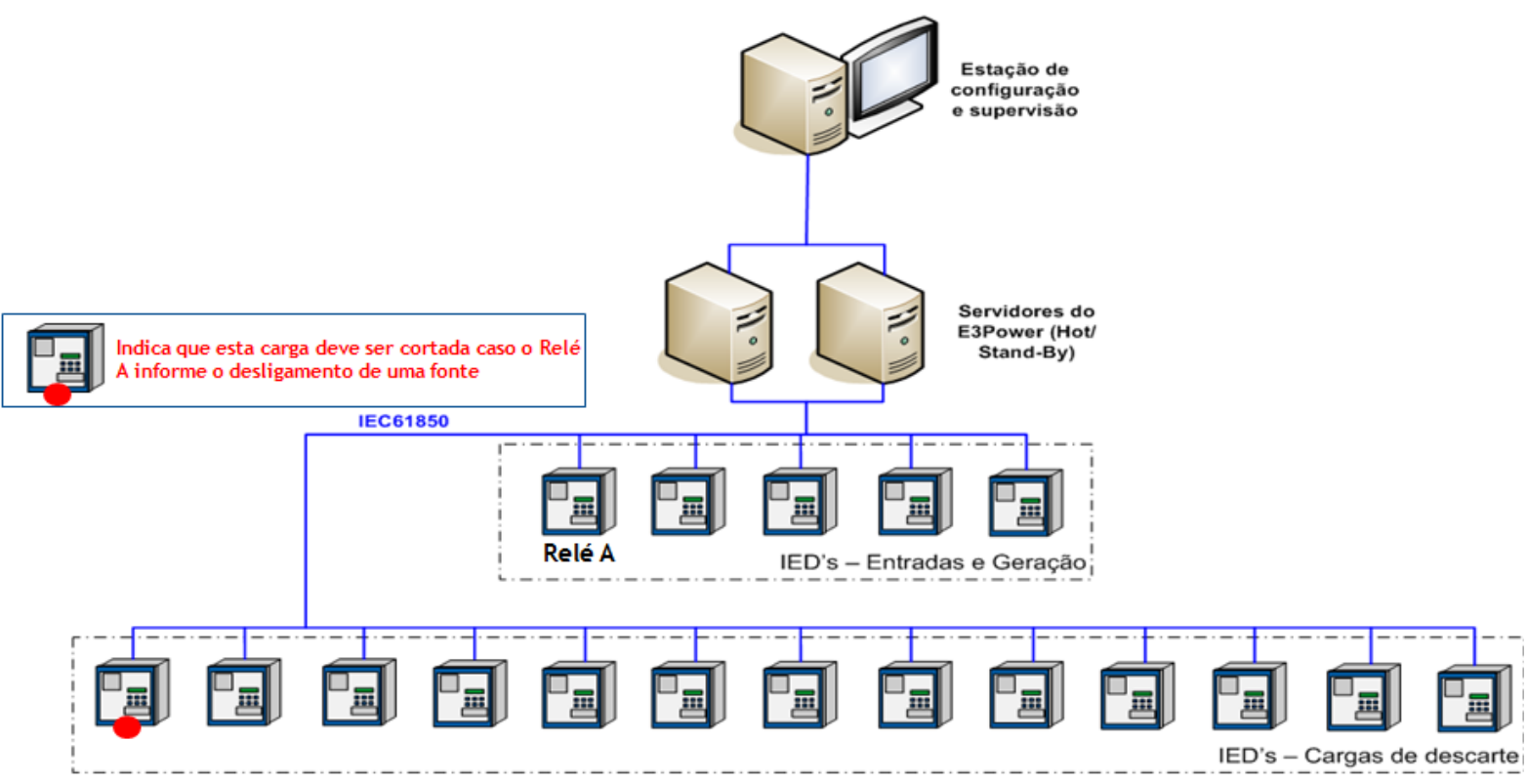

Figura 13 - Arquitetura Solução (ELIPSE, TUTORIAL ELIPSE POWER, 2012)

Nesta arquitetura, em dois computadores serão executados os servidores do software Elipse Power, que operam em contingência (Hot-Standby), ou seja, caso o servidor ativo apresente alguma falha o servidor em estado de espera (Standby) assumirá o processamento das informações evitando paradas no sistema. Além 
disso, outro computador funcionará como estação de operação, permitindo que os operadores efetuem a supervisão da indústria, através de telas sinóticas, e aloquem prioridades para as cargas do circuito, com o sistema em funcionamento.

O sistema supridor, cada um dos geradores e cada carga são alimentados por disjuntores controlados por IED's distribuídos ao longo da planta. Além disso, outro conjunto de IED's é responsável, exclusivamente, pela leitura das medições das potências e dos estados dos disjuntores do circuito. Todos os IED's estão conectados entre si e com os servidores do sistema de supervisão através de padrões estabelecidos pela norma IEC 61850.

Dessa forma, os IED's efetuam a leitura das medições de potências geradas e consumidas, além dos estados dos disjuntores do circuito elétrico da indústria, reportando estas informações ao servidor ativo do software de supervisão Elipse Power. Este software efetua a leitura das prioridades das cargas da indústria, ajustadas pelos seus operadores, através da interface gráfica que funciona na estação de operação. Em seguida, o sistema efetua a leitura do modelo elétrico que traduz o esquema unifilar da indústria. De posse das informações provenientes dos IED's e do modelo elétrico do sistema, o módulo Load Shedding constrói o cenário elétrico atual do sistema.

Em seguida o módulo Load Shedding do software de supervisão efetua a leitura dos possíveis eventos que caracterizam distúrbios no sistema de geração de energia, ou seja, o software identifica que a perda da alimentação complementar pela concessionária, ocasionada pela abertura do disjuntor DJ_Supridor, é o evento cadastrado e possível causador de desequilíbrio entre a geração e o consumo da indústria. O algoritmo, então, simula a ocorrência deste evento no cenário atual do sistema, utilizando seus módulos auxiliares de análise topológica e fluxo de potências para simulação dos efeitos de distúrbios na geração. Com base nas simulações e nas prioridades de cada carga, o módulo gera algumas ordens para desligamento de alguns disjuntores, que deverão abrir e providenciar o desligamento das cargas menos prioritárias. Finalmente, o sistema envia suas ordens de abertura de determinados disjuntores aos IED's. O resultado destas operações pode ser representado pela Figura 14, na qual os IED's destacados estão pré-sensibilizados para efetuarem o desligamento. 


\section{SISTEMA AUTOMÅTRCO DE ALIVIO DE CARGAS}

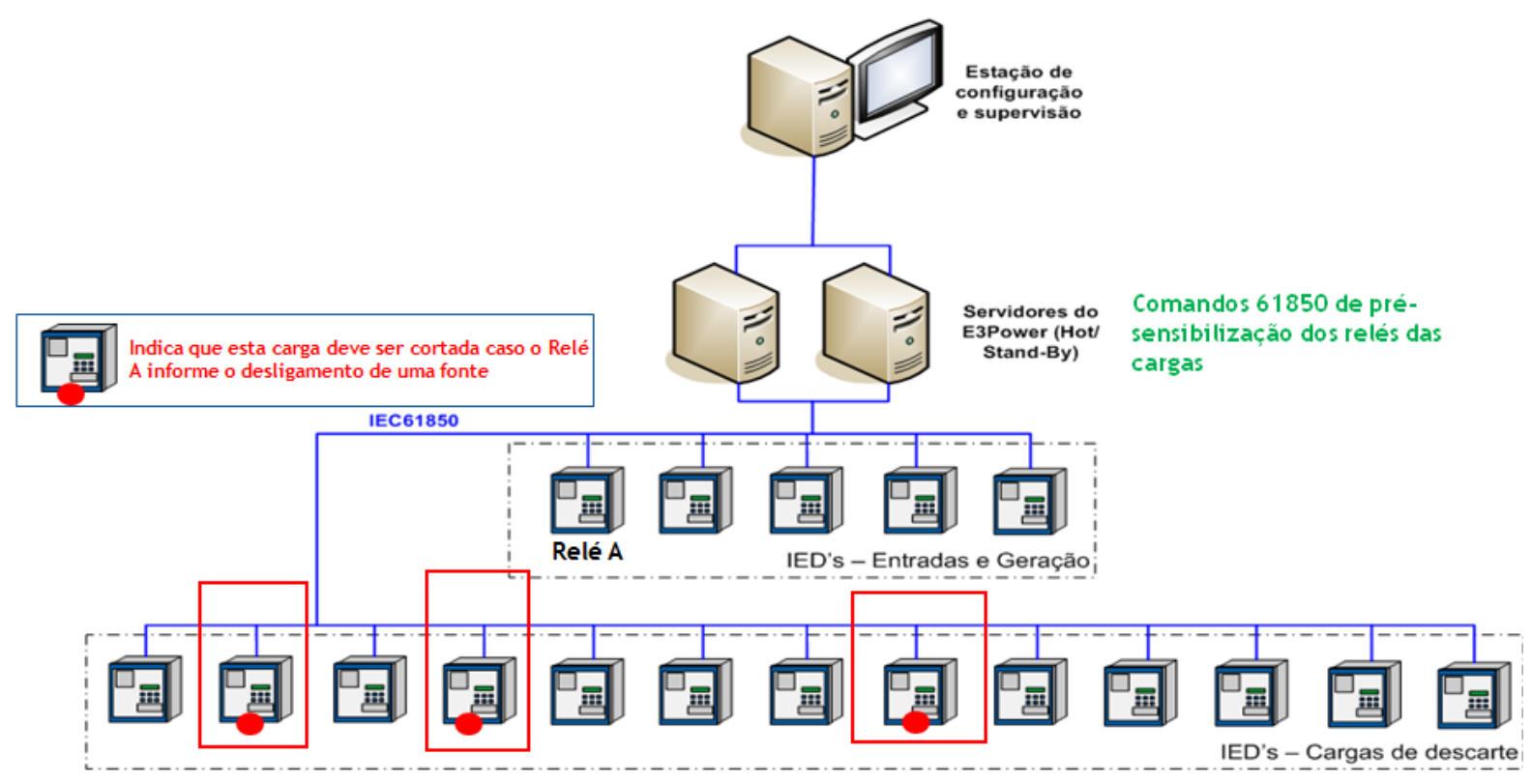

Figura 14 - Ordens de desligamento (ELIPSE, TUTORIAL ELIPSE POWER, 2012)

No entanto, quando as ordens de desligamento enviadas pelo sistema de supervisão chegam aos IED's, o desligamento ainda não ocorre, pois o evento de perda da concessionária ainda não ocorreu, foi somente simulado pelo algoritmo de alívio de cargas. Dessa forma, o sistema destaca-se pela sua ação preditiva, pois antes da ocorrência de um distúrbio na geração, o software já dispõe de uma lista com os disjuntores que devem abrir mediante a possível ocorrência dos eventos causadores de desequilíbrio entre a geração e o consumo de energia.

Para promover a abertura efetiva dos disjuntores e realizar o desligamento das cargas, os IED's devem possuir lógicas como mostra a Figura 15, que levam em consideração, além da ordem enviada pelo algoritmo de alívio de cargas do sistema de supervisão, o sinal correspondente a real ocorrência do evento já simulado pelo software e correspondente a um distúrbio na energia. 


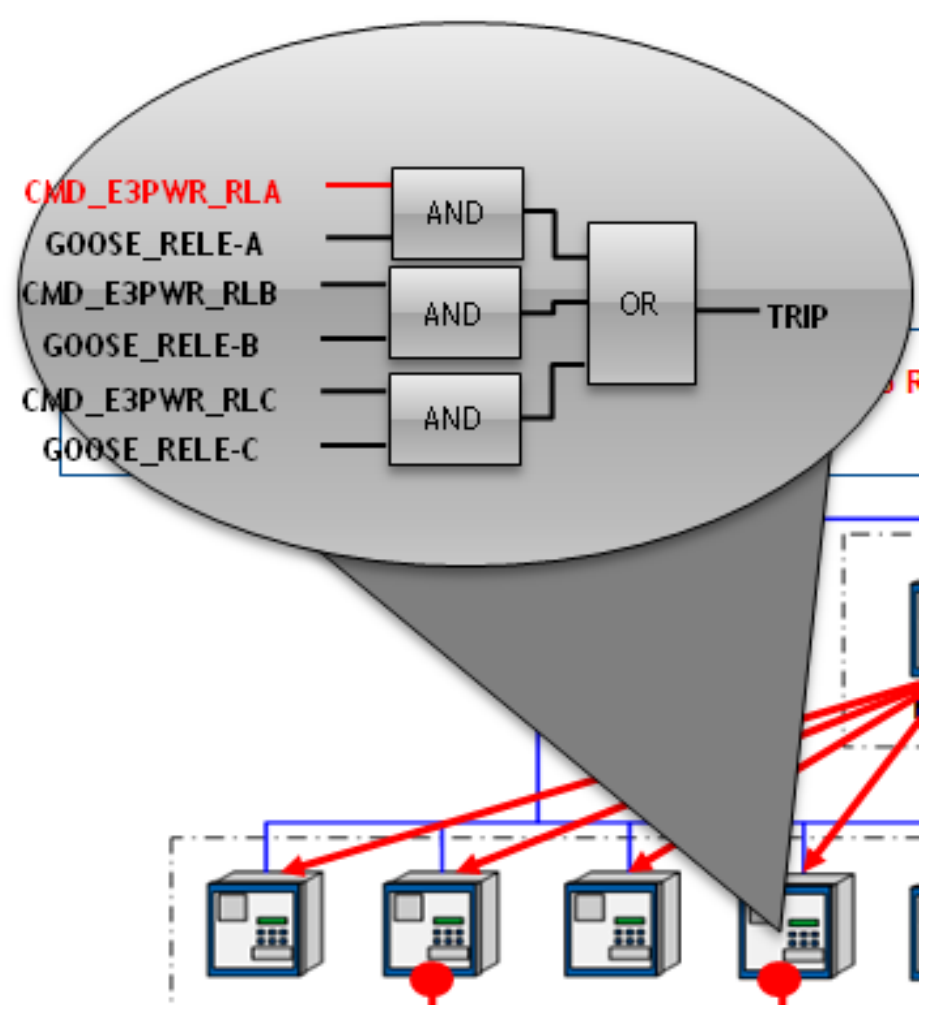

Figura 15 - Programação IED

Dessa forma, como o sistema de supervisão já efetuou suas simulações e transferiu as ordens de desligamento aos IED's, estes apenas aguardam o recebimento do sinal correspondente ao distúrbio na geração para promover o alívio de cargas. Assim, quando o disjuntor DJ_Supridor abrir, caracterizando a perda da alimentação pela concessionária, uma mensagem GOOSE será enviada pelo IED correspondente ao IED pré-sensibilizado pelo sistema de supervisão, completando as condições para que a lógica de desligamento seja disparada, provocando a abertura do disjuntor correspondente. Esta funcionalidade está exemplificada na Figura 16. 


\section{SISTEMAAUTOMARTICO DE ALINVIO DE CARGAS}

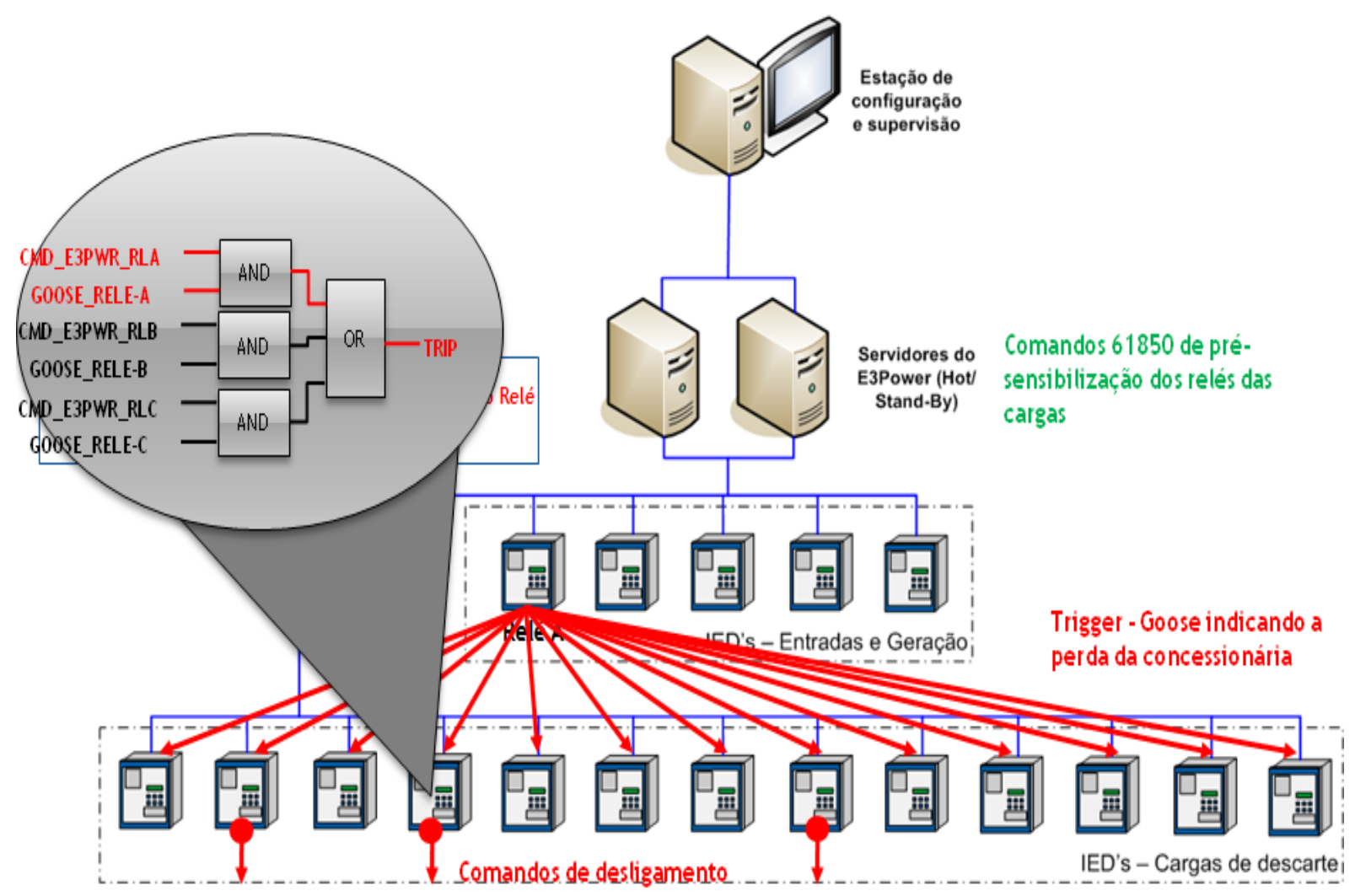

Figura 16 - Abertura disjuntor (ELIPSE, TUTORIAL ELIPSE POWER, 2012)

Como o sinal que informa a abertura do disjuntor DJ_Supridor é transferido entre os IED's, através de mensagens GOOSE, o sistema de supervisão não acarreta atrasos na atuação do sistema, que pode atuar em intervalos de tempo da ordem de 2 a 4 ms (Bulgarelli, Senger, Filho, Zerbinatti, Santos, \& Viceconti, 2005), tempo suficientemente curto para o restabelecimento entre o equilíbrio entre as potências consumidas e geradas pelo circuito remanescente. 


\subsection{CONFIGURAÇÃO DO SISTEMA PROPOSTO}

\subsubsection{Modelo elétrico}

Devido aos diferentes estados topológicos que o sistema elétrico pode apresentar e baseado na premissa que o resultado do módulo de alívio de cargas deve considerar todos os conjuntos fonte e carga possíveis de ocorrerem durante operação da rede elétrica, é essencial que o algoritmo possua o cadastro detalhado do sistema a ser controlado. Através da ferramenta de modelagem do supervisório é possível cadastrar todos os componentes de potência que constituem o sistema elétrico a ser controlado, tais como: linha de conexão com o sistema supridor, geradores, cargas, disjuntores e barras. Essa ferramenta possibilita a modelagem da interconexão entre tais equipamentos que compõe o sistema, disponibilizando uma interface gráfica que permite criar e visualizar as conexões entre os terminais dos equipamentos. 


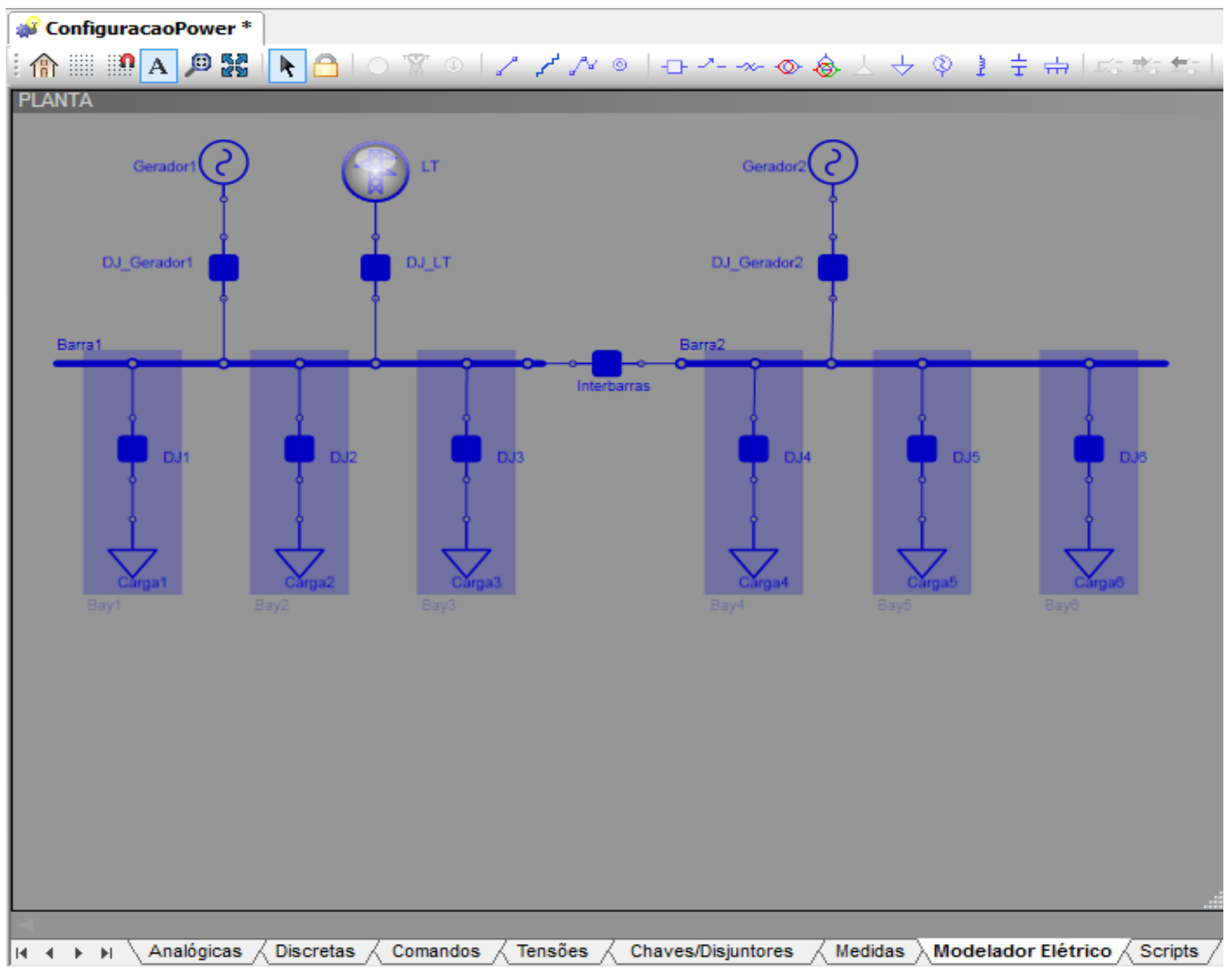

Figura 17 - Cadastro elétrico

\subsubsection{Comunicação do supervisório com IED's}

Após o cadastro dos equipamentos que compõem o diagrama unifilar da indústria, é necessário configurar o software supervisório para se comunicar com os IED's que controlam e protegem o sistema elétrico através do protocolo IEC 61850.

Para atingir este objetivo, o ambiente de engenharia do supervisório permite que seja criado um driver IEC 61850 responsável por efetuar a comunicação entre o software e todos os IED's do sistema, bem como definir as informações que formarão a base de dados do supervisório e que serão utilizadas pelo módulo de alívio de cargas. Nesse ambiente são definidos os endereços de rede de cada IED e 
os parâmetros específicos do protocolo de comunicação. A figura abaixo apresenta a janela de parametrização e seleção de pontos de comunicação do driver IEC 61850.

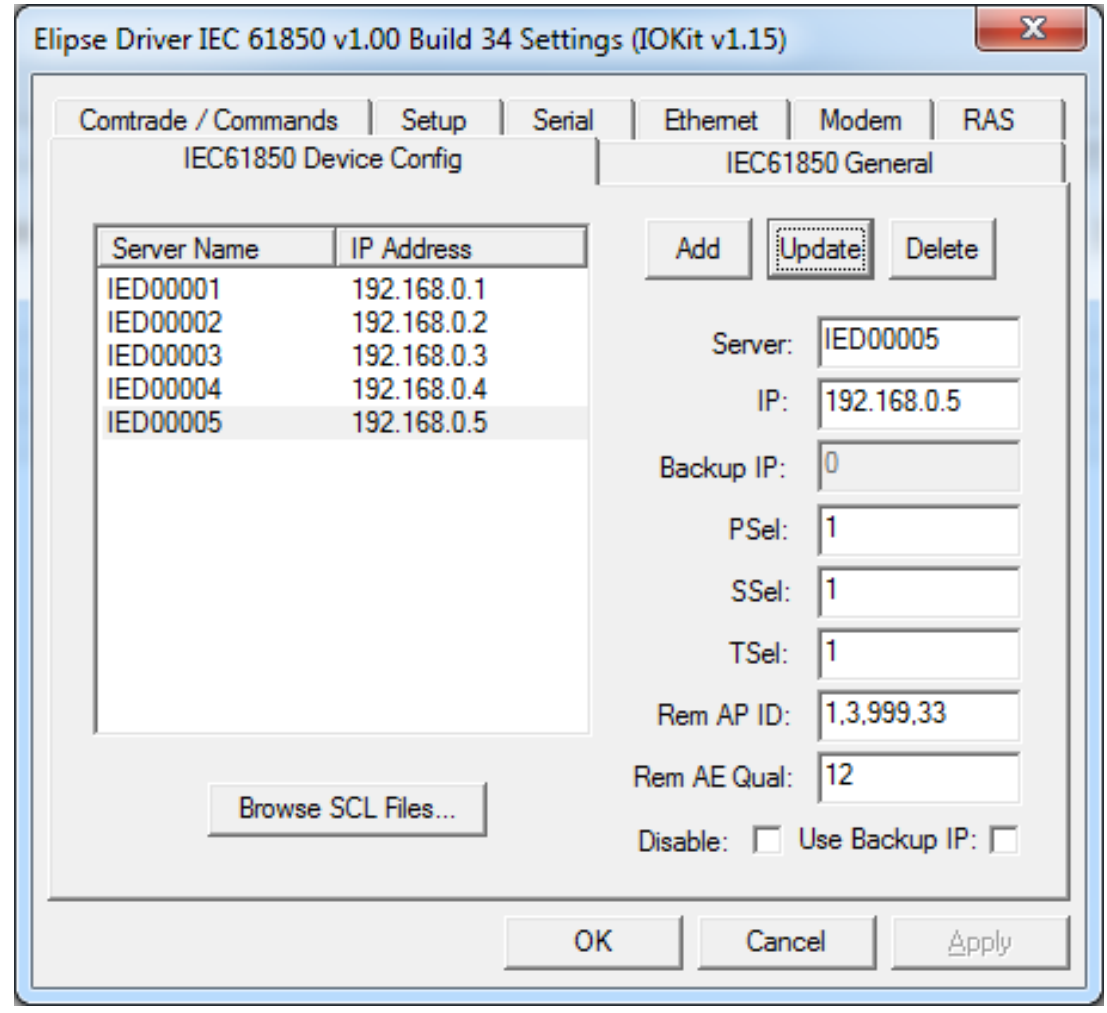

Figura 18 - Driver Elipse IEC 61850

O software supervisório possui uma estrutura hierárquica de objetos e pastas que permitem relacionar cada informação trocada com os IED's, pelo protocolo IEC 61850, com os respectivos dados correspondentes aos equipamentos cadastrados no modelador elétrico (disjuntores, chaves, transformadores, geradores, cargas, etc.) e que alimentarão o algoritmo adaptativo de alívio de cargas.

Dessa forma, a estrutura de pastas e objetos contribui para a contextualização de cada informação, ou seja, cada dado passa a contar com um significado elétrico que é interpretado pelo módulo Load Shedding do supervisório. Assim, o software permite que uma informação caracterizada por um nó lógico ( $L N)$ no IED conte com um significado de uma medida elétrica (tensão, corrente, potência, estado disjuntor, etc.) que é interpretada pelo módulo de alívio de cargas do supervisório. A Figura 19 apresenta um exemplo de contextualização de medidas de tensão, potência ativa e tensão de um dos geradores. 


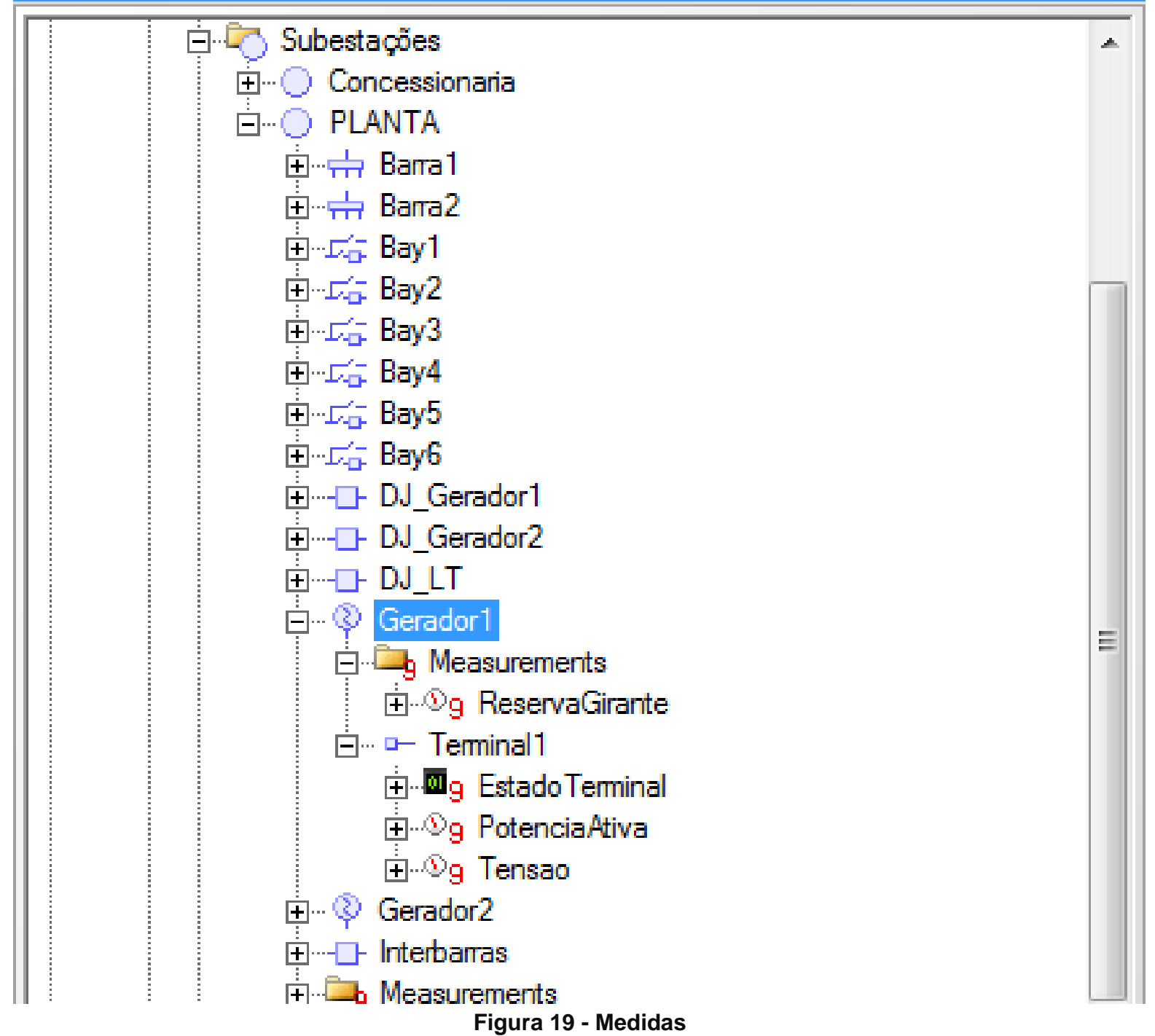

\subsubsection{Configuração do alívio de cargas}

No ambiente de modelagem elétrica, são identificados todos os disjuntores que estão aptos a participar do alívio de cargas, ou seja, aqueles disjuntores que caracterizam perda de alimentação ou que são instrumentos para desligamentos de cargas. Essa habilitação é realizada através de uma propriedade do objeto disjuntor do software supervisório chamada de HasLoadShedCtrl. Dessa forma, os disjuntores DJ_LT, DJ1, DJ2, DJ3, DJ4, DJ5 e DJ6 do sistema apresentado apresentam esta configuração para implementar o desligamento seletivo e 
sequencial das cargas Carga1, Carga2, Carga3, Carga4, Carga5 e Carga6 mediante a abertura do disjuntor DJ_LT, conforme resultado do algoritmo Load Shedding para que o balanço de potência do sistema fique estável.

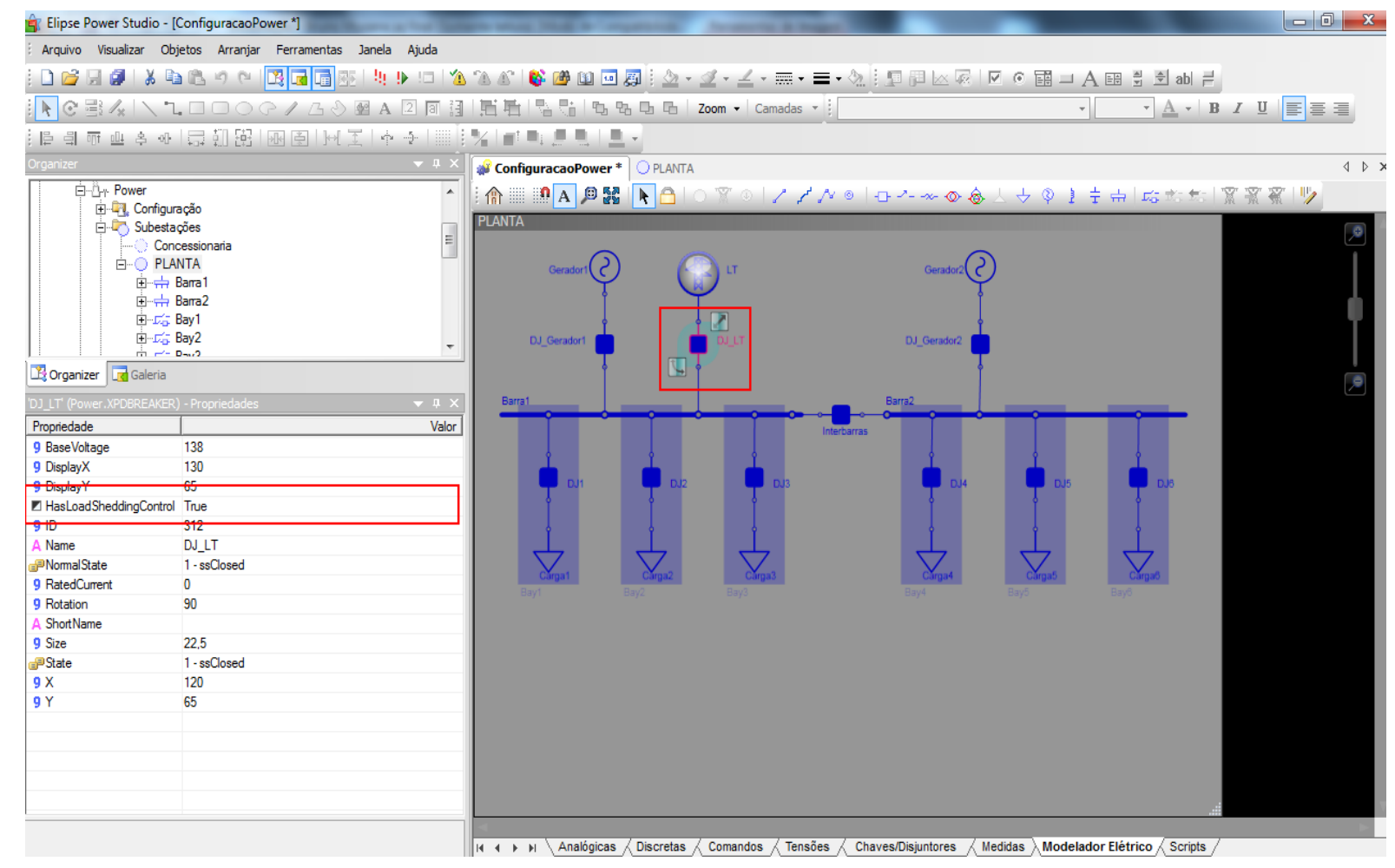

Figura 20 - Disjuntores do alívio de cargas

$\mathrm{Na}$ configuração do alívio de cargas, devem ser definidos os eventos de perda de geração a serem simulados (situações que devem provocar desequilíbrio). Cada cenário a ser simulado é constituído por uma lista de eventos, os quais serão aplicados sobre o cenário atual (estado topológico, geração e carregamento). O evento é caracterizado por uma ocorrência (abertura de um disjuntor, fechamento de uma chave, etc.) que é disparada sempre que ocorre uma alteração de estado de um determinado equipamento do sistema elétrico. Para o sistema apresentado, o evento a ser analisado se refere à perda da alimentação complementar (Perda_LT) do sistema supridor de energia da concessionária, que é caracterizado pela abertura do disjuntor DJ_LT. 


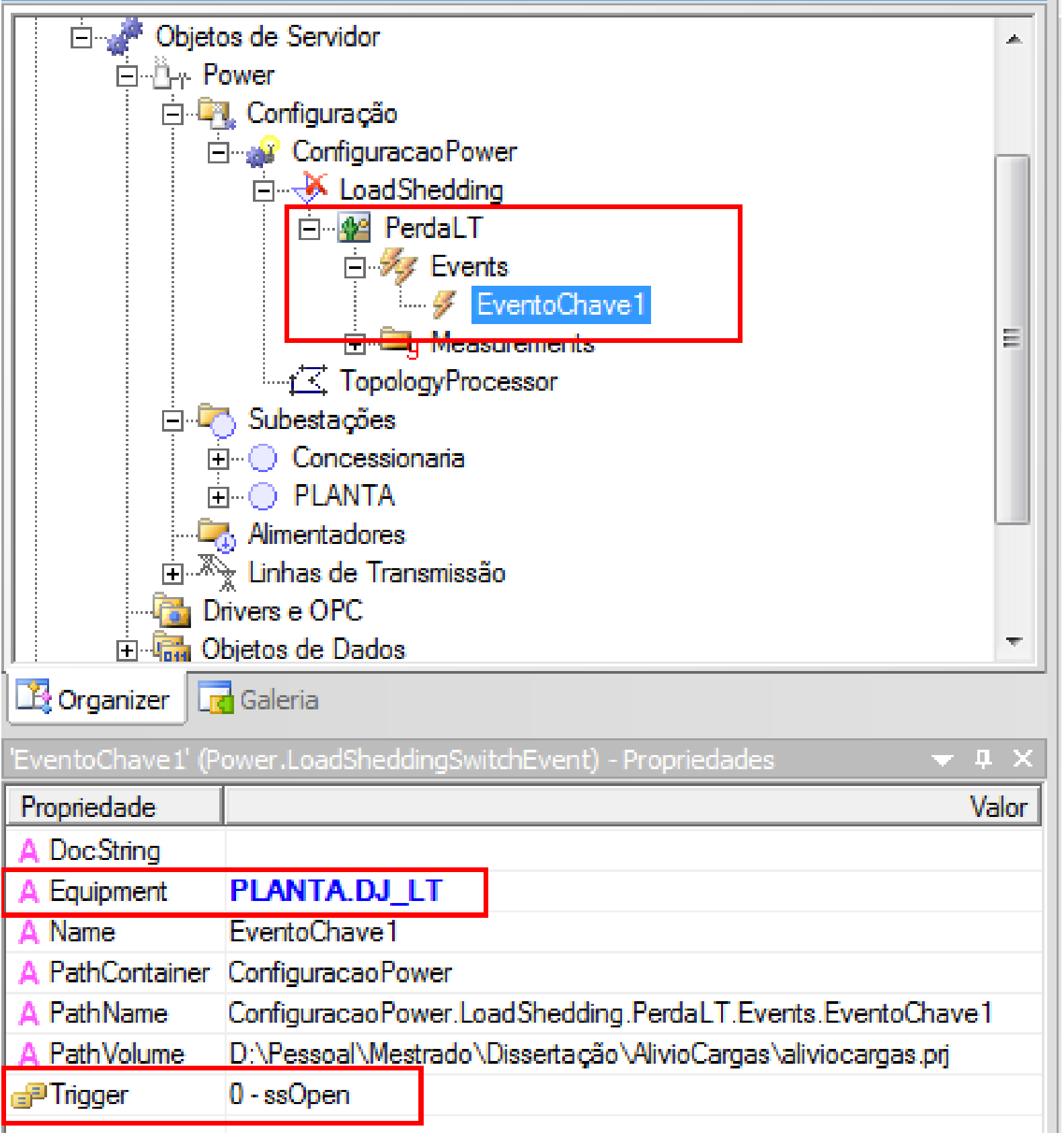

Figura 21 - Cenário Perda Concessionária

Na Figura 21, é possível ver um exemplo de configuração de alívio de carga que considera o evento de perda do sistema supridor que pode desestabilizar o sistema. Para pré-configurar a prioridade de cada carga, seleciona-se a medida PrioridadeDescarte, localizada dentro do respectivo objeto carga, seleciona-se a fonte Operator e altera-se o valor. Esse valor de prioridade pode ser alterado em execução do software por um usuário através de uma tela de operação. 
†...- Configuraça

$\square \cdot$ - Subestacóes

†... Concessionaria

$\square$ PLANTA

†…管 Barra1

†…沜 Barra2

Đ........ Bay1

$\square \cdot \cdots$ Carga1

$\square \rightarrow$ Measurements

†ํ.

†... - Teminal

†…ㅁ. D.J1

$\dagger \cdot \square^{-}$- Bay2

†... Bay3

†.'.5 Bay4

†.'. Bay 5

$\biguplus \cdots$ - Bay6

†..-—- D.J_Gerador1

†‥- $\square$ - DJ_Gerador2

†..-口- DJ_LT

†... Gerador1

†... Gerador2

†'-.- Interbarras

$+\cdots$ Measurements

6 Aimentadores

Ba , I T

Figura 22 Prioridade 


\subsection{DEMONSTRAÇÃO DO SISTEMA PROPOSTO}

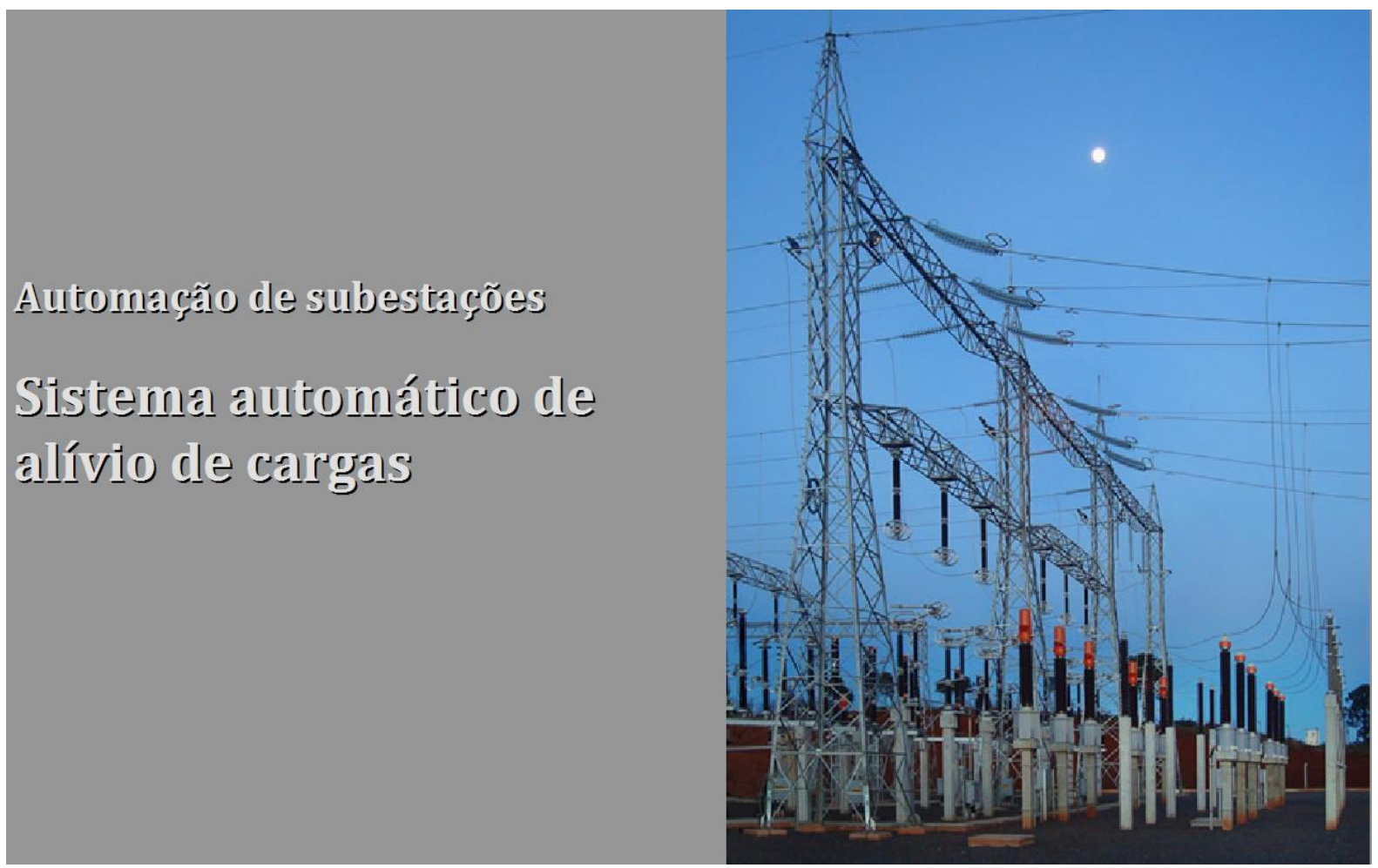

Figura 23 - Tela Inicial

Para demonstrar os resultados do sistema automático de alívio de carga apresentado neste trabalho, foi utilizada uma aplicação configurada conforme as etapas e os conceitos apresentados nos itens anteriores (CONFIGURAÇÃO DO SISTEMA e

Configuração do alívio de cargas), ou seja, customizou-se o software supervisório para simular o alívio de cargas do sistema descrito na Figura 12.

A Figura 24 mostra a tela sinótica do diagrama unifilar da indústria para demonstração do sistema automático de alívio de carga. 


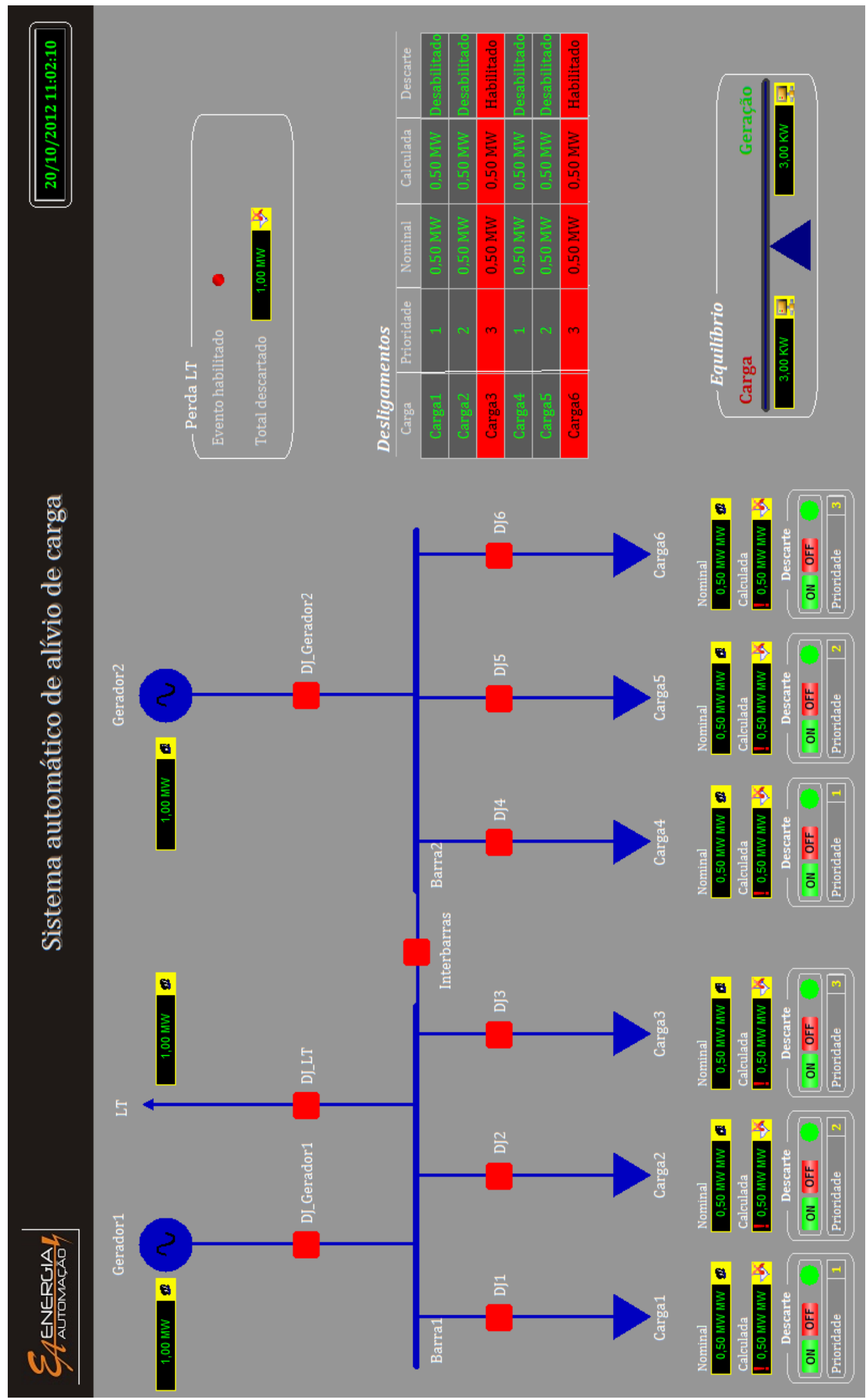

Figura 24 - Tela Unifilar 
Através da tela representada na Figura 25, o usuário é capaz de efetuar a configuração das prioridades de cada carga da indústria. Para isso basta digitar um número inteiro de um a três, onde três é prioridade mais baixa de permanecer ligada, no campo correspondente à carga desejada e pressionar a tecla Enter do teclado.

Além disso, o usuário do sistema tem a opção de habilitar e desabilitar a participação do disjuntor de cada carga no algoritmo de alívio. Para isso basta pressionar o botão correspondente na tela e o estado de participação do disjuntor será mostrado em um texto.

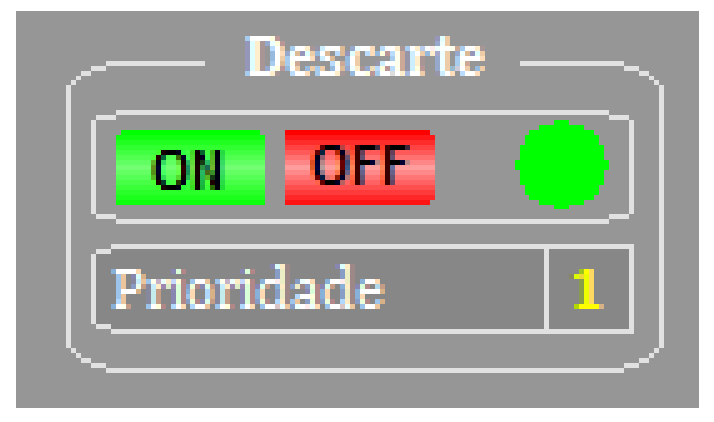

Figura 25 - Configuração Cargas

Através da tela correspondente à Figura 26, o sistema informa ao usuário sobre a quantidade de potência que será desligada, caso ocorra o evento correspondente à perda do sistema supridor.

Além disso, esta tela informa ao usuário quais cargas serão desligadas caso ocorra à perda do sistema supridor. Para isso as linhas correspondentes às cargas a serem desligadas ficam sublinhadas em vermelho. 


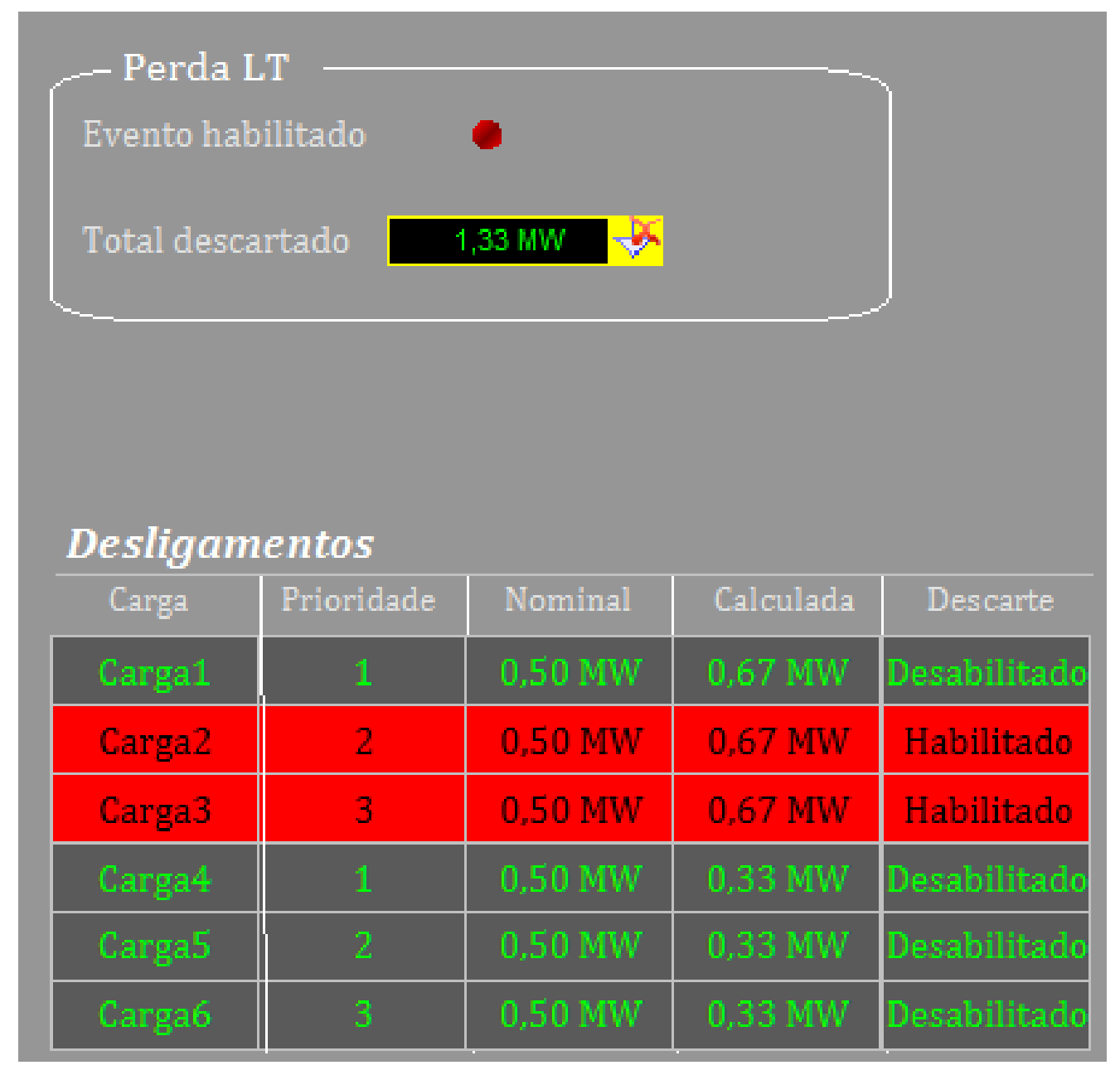

Figura 26 - Cargas desligadas

Os resultados do sistema automático para o alívio de cargas serão demonstrados para os seguintes cenários:

\subsubsection{Barras 1 e 2 isoladas}

Caso o disjuntor interbarras da indústria encontre-se aberto (conforme mostra a Figura 27), as duas barras de geração (Barra1 e Barra2) estarão isoladas, ou seja, o sistema supridor alimentará somente os bays correspondentes às cargas 1,2 e 3 . Dessa forma, as cargas 4, 5 e 6 serão alimentadas exclusivamente pela Barra2 de geração, ou seja, essas cargas ficarão automaticamente fora do algoritmo de alívio de cargas por não estarem conectadas ao sistema supridor.

Dessa forma, o algoritmo de alívio de cargas do software Elipse Power poderá efetuar a pré-sensibilização dos disjuntores DJ1, DJ2 e DJ3 para efetuarem o 
desligamento das cargas 1, 2 e 3, conforme as prioridades atualmente escolhidas pelo usuário. Neste cenário, o usuário do sistema ajustou as prioridades para as cargas conforme a Figura 27, ou seja, após a simulação da ocorrência do evento de perda do sistema supridor ao cenário apresentado, o sistema de alívio de cargas pré-sensibilizará 0 desligamento das cargas 2 e 3 , através da abertura dos disjuntores DJ2 e DJ3. 


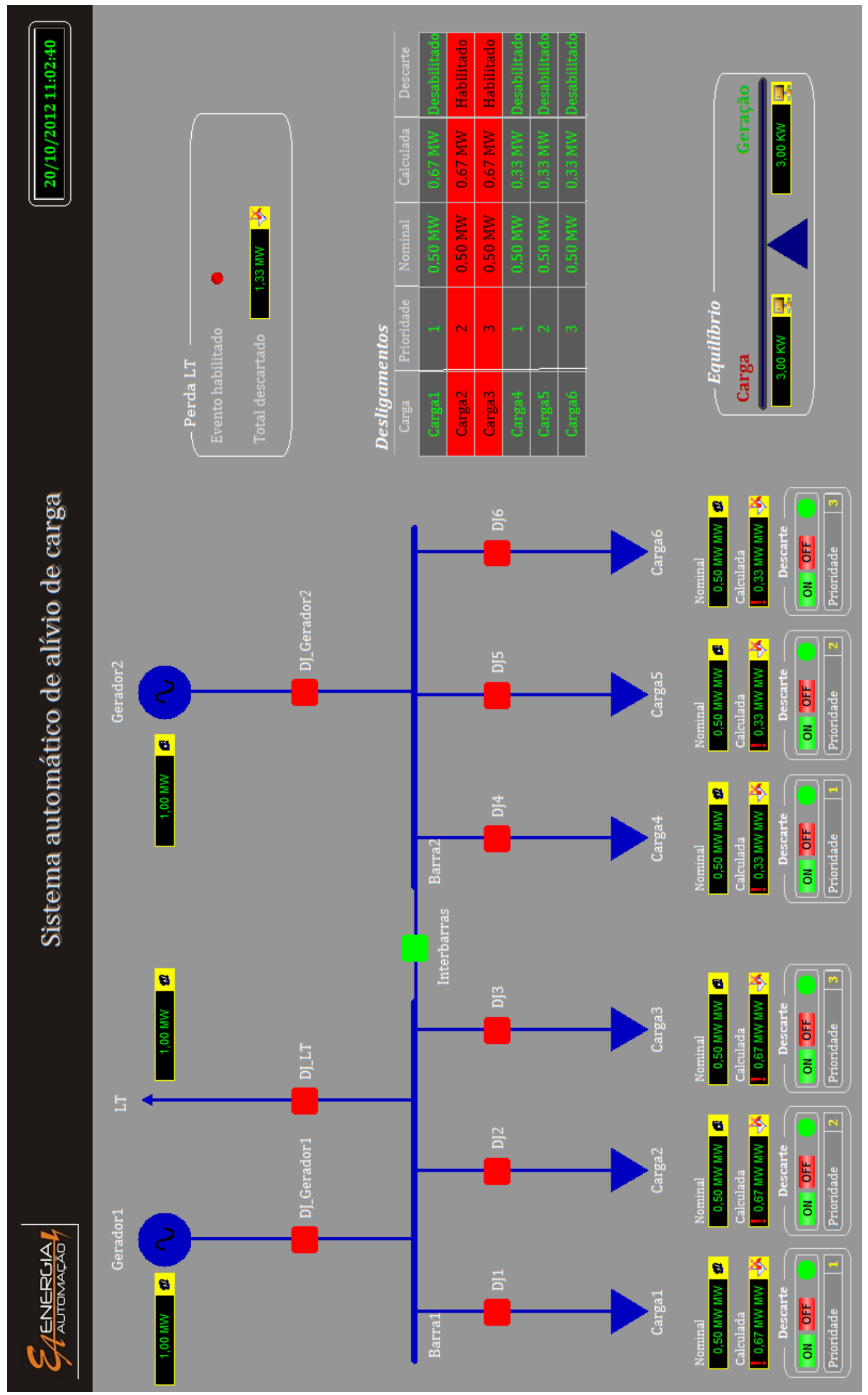

Figura 27 - Barras isoladas 


\subsubsection{Barras 1 e 2 conectadas}

Caso o disjuntor interbarras da planta elétrica encontre-se fechado (conforme mostra a Figura 28), as duas barras de geração (Barra1 e Barra2) estarão conectadas, ou seja, o sistema supridor e os geradores (Gerador 1 e Gerador 2) alimentarão todos os bays correspondentes às cargas 1, 2, 3, 4, 5 e 6. Dessa forma, o sistema se comportará como um único bloco com seis alimentadores e três fontes de energia, ou seja, todas as cargas ficarão automaticamente dentro do algoritmo de alívio de cargas.

Dessa forma, o algoritmo de alívio de cargas do software Elipse Power poderá efetuar a pré-sensibilização de qualquer um dos disjuntores dos bays alimentadores para habilitar o desligamento das cargas, conforme as prioridades atualmente escolhidas pelo usuário.

Neste cenário, o usuário do sistema ajustou as prioridades para as cargas conforme a Figura 28, ou seja, após a simulação da ocorrência do evento de perda do sistema supridor ao cenário apresentado, o sistema de alívio de cargas pré-sensibilizará o desligamento das cargas 3 e 6, através da abertura dos disjuntores DJ3 e DJ6. 


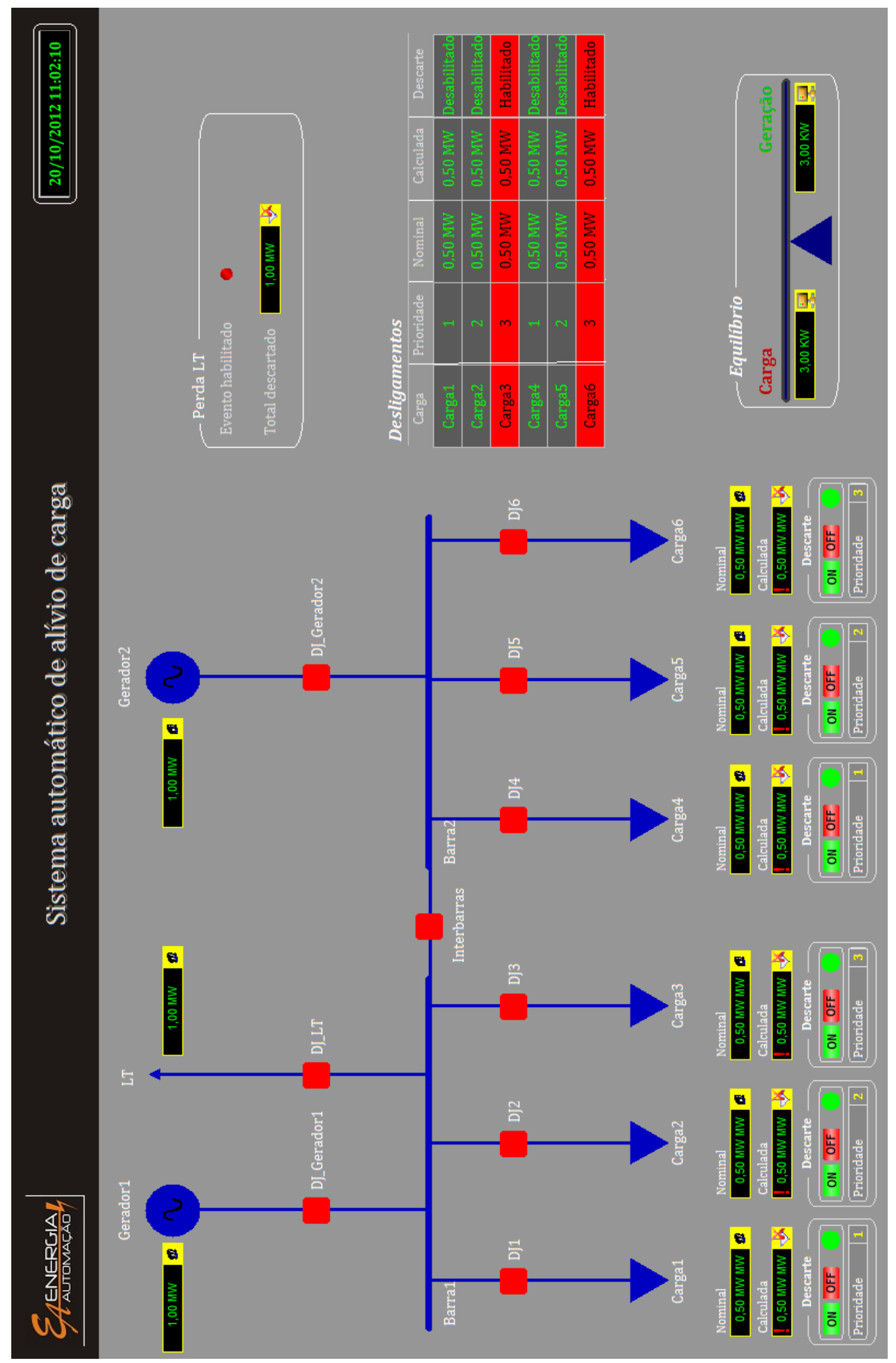

Figura 28 - Barras conectadas 


\subsection{3 Única geração}

Caso a indústria apresente somente uma fonte de geração Gerador 1 ou Gerador 2, conforme mostra a Figura 29, as duas barras de geração (Barra1 e Barra2) estarão sempre alimentadas por uma fonte de geração (Gerador 1 ou Gerador 2) e pelo sistema supridor, ou seja, o sistema supridor e um dos geradores (Gerador 1 ou Gerador 2) alimentarão todos os bays correspondentes às cargas 1, 2, 3, 4, 5 e 6 . Dessa forma, o sistema se comportará como um único bloco com seis alimentadores e duas fontes de energia, ou seja, todas as cargas ficarão automaticamente dentro do algoritmo de alívio de cargas.

Dessa forma, o algoritmo de alívio de cargas do software Elipse Power poderá efetuar a pré-sensibilização de qualquer um dos disjuntores dos bays alimentadores para habilitar o desligamento das cargas, conforme as prioridades atualmente escolhidas pelo usuário.

Neste cenário, o usuário do sistema ajustou as prioridades para as cargas conforme a Figura 29, ou seja, após a simulação da ocorrência do evento de perda do sistema supridor ao cenário apresentado, o sistema de alívio de cargas pré-sensibilizará o desligamento das cargas 3,5 e 6 , através da abertura dos disjuntores DJ3, DJ5 e DJ6. 


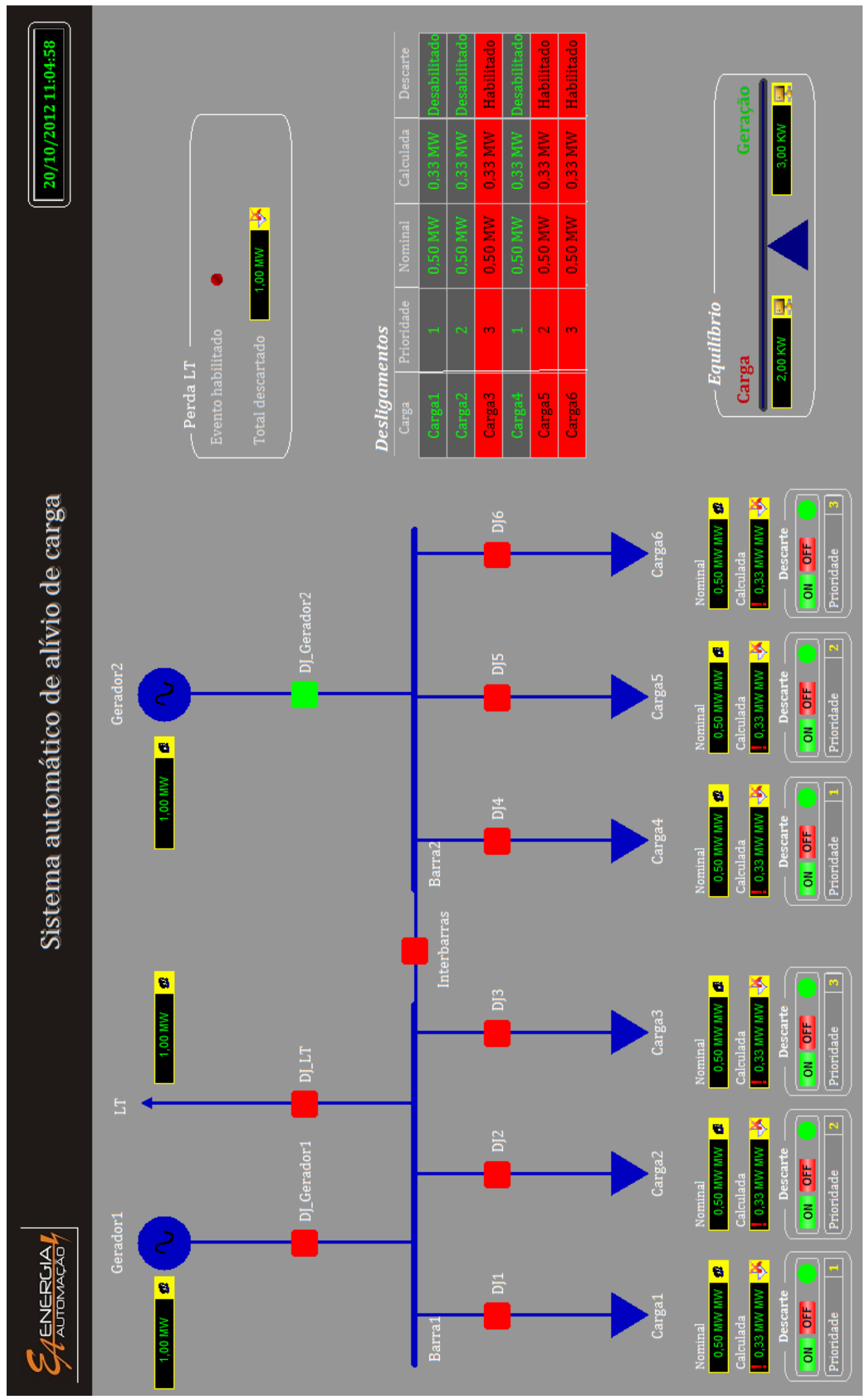

Figura 29 - Gerador 2 isolado 


\section{CONCLUSÕES}

Atualmente, muitas plantas industriais trabalham com uma composição mista para geração da energia elétrica consumida em seus processos, onde parte da potência é suprida por um alimentador conectado a uma concessionária e outra parte é fornecida por geradores próprios abastecidos pela própria indústria. Esta configuração de sistema elétrico é conhecida como co-geração e auxilia as indústrias a diminuírem seu consumo de energia das concessionárias e manter o equilíbrio entre geração e carga.

No entanto, na hipótese de falta repentina do sistema supridor de energia, a remoção rápida e seletiva de algumas cargas pode possibilitar que o sistema permaneça em equilíbrio, evitando assim um desligamento prolongado de todas as cargas. Este tipo de filosofia é conhecido por Esquema de Alívio de Cargas, sendo uma tentativa de restabelecer o balanço de potência entre a produção e o consumo. A maioria dos sistemas de alívio de cargas existentes nas indústrias, baseiam-se em algoritmos estáticos, que levam em consideração números fixos de cargas, e são implementados através de relés de frequência e sistemas de controle que são disparados após perturbações no sistema elétrico, o que pode acarretar desligamentos desnecessários e até danificar geradores conectados à subestação.

Com a evolução dos equipamentos inteligentes de campo, das redes, dos protocolos de comunicação e dos sistemas de supervisão e aquisição de dados, se torna possível implementar um sistema adaptativo de alívio de carga, que por sua vez, não desligue um número pré-definido de circuitos, mas uma quantidade de carga necessária para restabelecer o equilíbrio do sistema, baseado na quantidade de potência ativa que deixou de ser fornecida no momento.

O sistema de alívio de cargas deve permitir que prioridades sejam ajustadas para cada carga a qualquer momento pelos seus usuários, deve simular os cenários elétricos constantemente e pré-sensibilizar os IED's responsáveis pelo desligamento das cargas antes que ocorra um evento que prejudique o balanço de potência do sistema elétrico.

As definições de rede e de protocolo de comunicação convencionadas pela norma IEC 61850 viabilizam a implantação desse tipo de sistema, pois torna possível o uso de diversos IED's que promovem a medição continua da potência em cada 
alimentador e recebe os estados de chaves e de disjuntores da subestação, enviando todos os valores constantemente ao responsável pelo algoritmo de alívio de carga. Além disso, o protocolo IEC 61850 estabelece e define as diretrizes para promover troca de mensagens GOOSE entre IED's, de forma que quando ocorre um evento de disparo de um cenário de alívio de cargas e o IED estiver présensibilizado pelo algoritmo, o desligamento de cargas ocorre em tempo suficientemente curto para que o sistema permaneça em equilíbrio.

Logo, este trabalho apresenta uma solução desenvolvida através de um software de supervisão de mercado que executa seu algoritmo e pré-sensibiliza equipamentos inteligentes de campo (IED's), conectados através de rede Ethernet TCP/IP e protocolo IEC 61850, para o desligamento de cargas de um sistema elétrico de uma indústria com co-geração em caso de distúrbio com o intuito de minimizar o impacto do desequilíbrio e garantir a equalização entre as potências geradas e consumidas no circuito (alívio de carga). 


\section{REFERÊNCIAS}

BULGARELLI, R. Novo sistema digital de proteção e automação de sistema elétrico de distribuição de uma refinaria de petróleo baseado em IED e em protocolo IEC 61850. Rio de Janeiro, 2006.

BULGARELLI, R., SENGER, E. C., FILHO, F. A., ZERBINATTI, P. E., SANTOS, A. D., \& VICECONTI, E. A. Modelamento e ensaios de sistema digital de proteção e automação de sistema elétrico de distribuição de umarefinaria de petróleo baseado em ied e em protocolo IEC 61850. São Paulo, 2005.

CARVALHO, P. C. www.altus.com.br. Disponível em:

http://altus.com.br/site_ptbr/index.php?option=com_downloadsaltus\&view=download saltus\&ltemid=54\&newpath=Portugues\%2FAltus\%20Institucional\%2FArtigos\%20Tec nicos. Acesso em: Novembro de 2010.

COMMISSION, I. E. IEC 61850-1: Communication networks and systems in substations - Part 1 Introduction and overview. Geneva, 2003.

IEC 61850-2: Communication networks and systems in substations - Part 2: Glossary. Geneva, 2003.

IEC 61850-5: Communication networks and systems in substations - Part 5 Communication requirements for functions and device models. Geneva, 2003.

. IEC 61850-6: Communication networks and systems in substations - Part 6 Configuration description language for communication in electrical substations related to IEDs Introduction and overview. Geneva, 2004.

IEC 61850-7-1: Communication networks and systems in substations - Part 7-1: Basic communication structure for substation and feeder equipment - Principles and models. Geneva, 2003.

IEC 61850-7-1: Communication networks and systems in substations - Part 7-1: Basic communication structure for substation and feeder equipment - Principles and models. Geneva, 2003.

. IEC 61850-7-2: Communication networks and systems in substations - Part 7-2: Basic communication structure for substation and feeder equipment - Abstract communication service interface (ACSI). Geneva, 2003.

IEC 61850-7-3: Communication networks and systems in substations - Part 7-3: Basic communication structure for substation and feeder equipment - Common data classes. Geneva, 2003. 
IEC 61850-8-1: Communication networks and systems in

substations - Part 8-1: Specific Communication Service Mapping (SCSM) Mappings to MMS (ISO 9506-1 and ISO 9506-2) and to ISO/IEC 8802-3. Geneva, 2004.

IEC 61850-9-1: Communication networks and systems in substations - Part 9-1: Specific Communication Service Mapping (SCSM) - Sampled values. Geneva, 2004.

IEC 61850-7-4: Communication networks and systems in substations - Part 7-4: Basic communication structure for substation and feeder equipment - Compatible logical node classes and data classes. Geneva, 2003.

CRISPINO, F., VILLACORTA, C. A., OLIVEIRA, P. R., JARDINI, J. A., \& MAGRINI, L. C. Uma experiência aplicando um padrão Orientado a Objeto: IEC . São Paulo, São Paulo, Brasil, 2008.

Elipse. Manual do Elipse POWER, 2013.

Elipse.Tutorial Elipse POWER, 2012.

Guerrero, C. A. Uso do RTDS em Testes de Esquemas de Teleproteção aplicando o Padrão IEC 61850. Itajubá, Minas Gerais, Brasil, 2011.

GURJÃO, E., CARMO, U., \& SOUZA, B. Aspectos de comunicação da norma IEC 61850. Simpósio Brasileiro de Sistemas Elétricos - SBSE 2006 , 1, pp. 1-5, 2006.

MUSARRA, B. C., \& JARDINI, J. A. Automação de subestações - Sistema automático de alívio de carga. In: Sixth IEEE/PES Transmission and Distribution: Latin America Conference and Exposition (T\&D-LA), 2012.

PAULINO, M. E., SIQUEIRA, I. P., \& CARMO, U. A. Requisitos para Interoperabilidade de IEDS e Sistemas Baseados na Norma IEC61850. STPC Seminário Técnico de Proteção e Controle, 2010.

PEREIRA, A. C., ABBOUD, R., PELLIZZONI, R., ZANIRATO, E., \& CACERES, D. Sistemas de proteção e automação de subestações de distribuição e indústrias usando a norma iec 61850. XIII Eriac Décimo Tercer Encuentro Regional Iberoamericano de Cigré, 2009.

PINHEIRO, J. M. O modelo OSI. 2004. Disponível em: http://www.projetoderedes.com.br/artigos/artigo_modelo_osi.php.

SEL - Equipe de engenharia da Schweitzer Engineering Laboratories. Redes de comunicação em subestações de energia elétrica - Norma IEC 61850.

Disponível em:

http://www.osetoreletrico.com.br/web/documentos/fasciculos/Ed54_fasc_automacao _subestacoes_capVII.pdf. Acesso em: Janeiro de 2013. 
WIKIPÉDIA. Modelo OSI. Disponível em: http://pt.wikipedia.org/wiki/Modelo_OSI. Acesso em: Janeiro de 2013. 